\title{
UTILIZAÇÃO DE FOTOGRAFIAS NA DETERMINAÇÃO DA PORCENTAGEM DE COBERTURA VEGETAL DO SOLO PELO MILHO (Zea mays)
}

\section{JULIO RENÁN PANIAGUA ALCARAZ}

Engenheiro Agrônomo

Orientador: Prof._Dr. JÚLIO VASQUES FILHO

Dissertação apresentada à Escola Superior de Agricultura "Luiz de Queiroz", da Universidade de São Paulo, para a obtenção do título de Mestre em Agronomia, Área de Concentração: Solos e Nutrição de Plantas.

P I R A C I C A B A

Estado de São Paulo - Brasil

Novembro - 1996 
Dados Internacionais de Catalogaçāo na Publicaçāo (CIP)

DIVISÃO DE BIBLIOTECA E DOCUMENTAÇẪO - Campus "Luiz de Queiroz"/USP

Paniagua Alcaraz, Julio Renán

Utilização de fotografias na determinação da porcentagem de cobertura vegetal do solo pelo milho (Zea mays L.) / Julio Renán Paniagua Alcaraz. - - Piracicaba, 1996.

71 p. : il.

Dissertação (mestrado) - - Escola Superior de Agricultura Luiz de Queiroz, 1997. Bibliografia.

1. Fotografia na pedologia 2. Mitho - Cultivo 3. Solo - Cobertura vegetal - Determinação I. Título.

CDD 634.15

633.45 


\section{UTILIZAÇÃO DE FOTOGRAFIAS NA DETERMINAÇÃO DA PORCENTAGEM DE COBERTURA VEGETAL DO SOLO PELO MILHO \\ (Zea mays)}

\section{JULIO RENÁN PANIAGUA ALCARAZ}

Aprovada em: 22/01/1997.

Comissão julgadora:

Prof. Dr. Júlio Vasques Filho

ESALQ/USP

Prof. Dr. José Alexandre de Mello Demattê

ESALQ/USP

Prof. Dr. Vicente de Paula Pereira

UNESP/ Jaboticabal

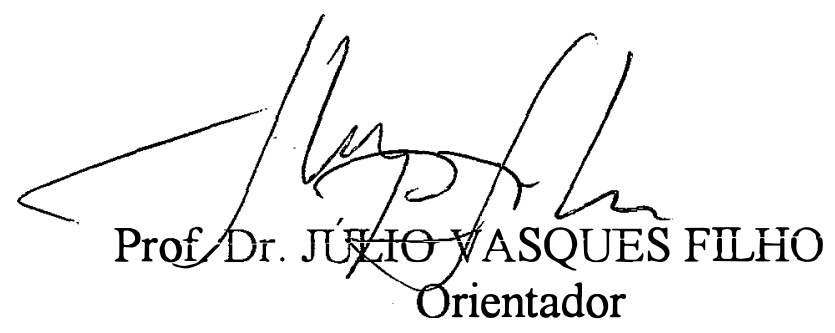


Aos meus pais

Gregorio Renán e Tita Margarita OFEREÇO

A minha esposa Claudia Rocío e a minha filha Paula Alejandra DEDICO. 


\section{AGRADECIMENTOS}

Ao Prof. Dr. Júlio Vasques Filho, pela orientação e apoio, por ter incentivado para a realização deste trabalho.

Ao Ministério de Agricultura e Ganadería da República do Paraguay pela oportunidade dada para a realização do curso de pós-graduação.

Ao CNPq, pela bolsa de estudos concedida durante a realização do Curso de pós-graduação.

Ao Prof. Dr. Humberto de Campos e ao Prof. Dr. Rodolfo Hoffman pela ajuda na análise estatística dos dados obtidos.

À EMBRAPA/CNPDIA, na pessoa do Eng. Lúcio André de Castro Jorge, pelo apoio na análise das fotografias via computador.

Aos colegas de turma Fernando Luis Dultra Cintra, Efrain Trejo Chandias, Jorge Ramón Laines e Ariel Ortiz, pela amizade e ajuda durante o curso de pós-graduação.

Ao colega Luis Fernando Servín Villalba pela ajuda na construção da estrutura metálica utilizada no trabalho.

A Juan Alcaraz e Andrés Lai Reyes pela ajuda e asessoramento em Informática.

Ao Grupo de Experimentação Agropecuária (GEA) do Departamento de Agricultura da ESALQ, pela ajuda nos trabathos de campo. 


\section{SUMÁRIO}

Página

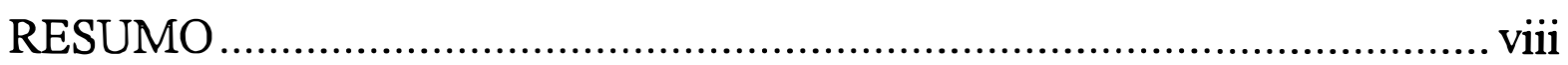

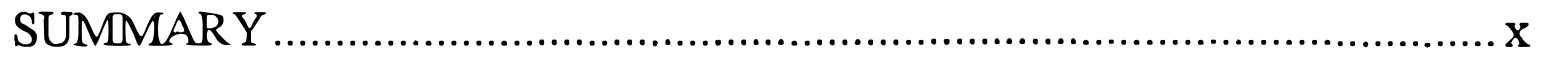

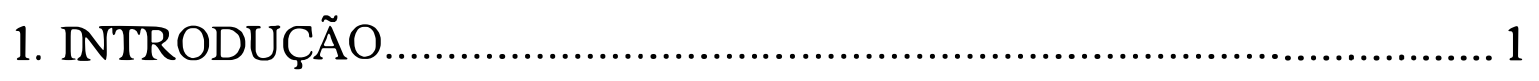

2. REVISÃO DE LITERATURA …................................................. 3

2.1. Dimensionamento da cobertura vegetal no processo

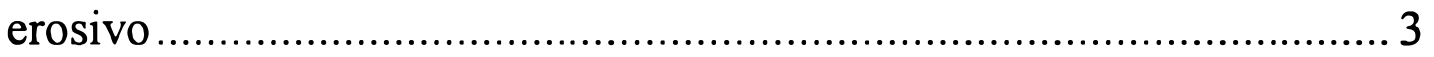

2.2. Variação da distribuição da cobertura vegetal .................................... 5

2.3. A cultura do milho: ciclo vegetativo e aspectos

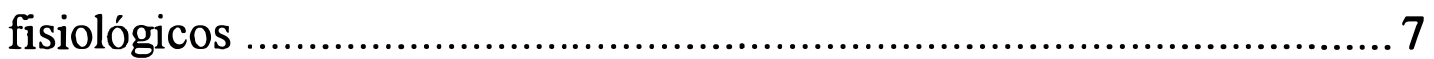

2.4. Relação entre a porcentagem de cobertura vegetal e altura

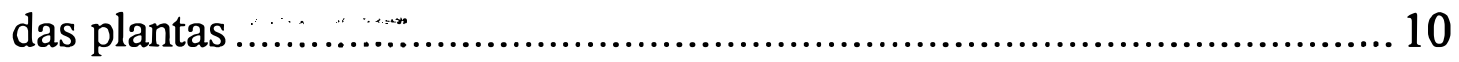

2.5. Métodos utilizados para a determinanção da porcentagem

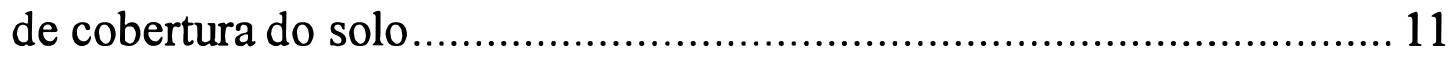

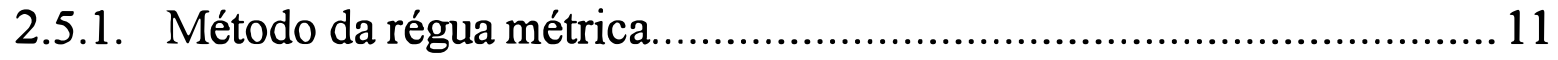

2.5.2. Método do cavalete com visores .............................................. 12

2.5.3. Método da corda com marcas ................................................... 14

2.5.4. Método de intercepção de luz ...................................................... 15

2.5.5. Método da largura do dossel vegetativo ......................................... 15

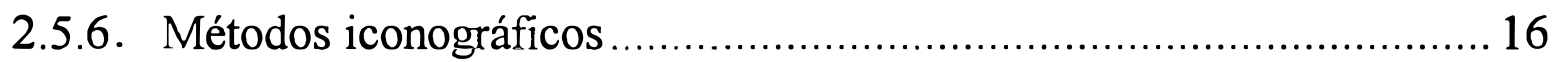

2.5.6.1. Obtenção das imagens........................................................... 17

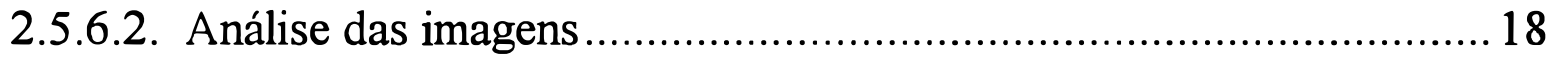




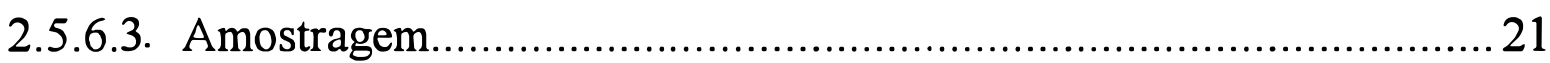

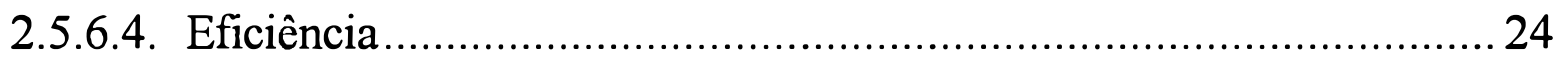

2.5.6.5. Comparação entre o método fotográfico e outros métodos de determinação da cobertura vegetal do solo .................................27

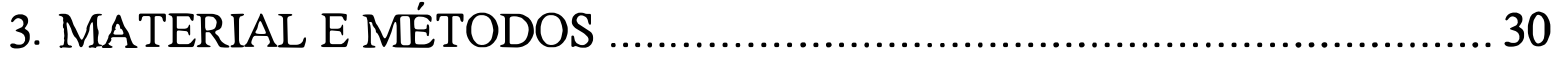

3.1. Caracterização do local do experimento ………………………….......... 30

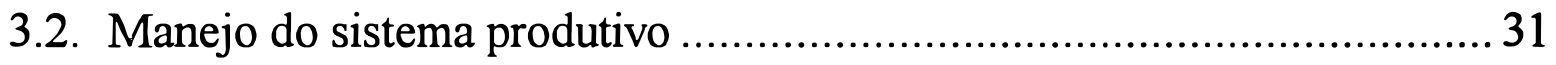

3.2.1. Preparo do solo, aplicação de herbicida e semeadura ......................... 31

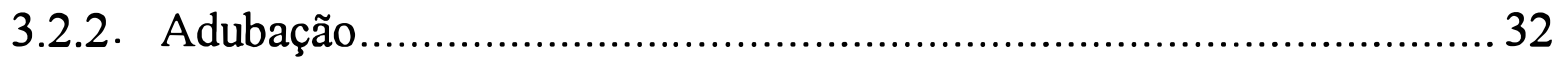

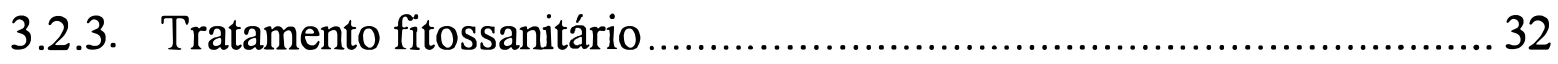

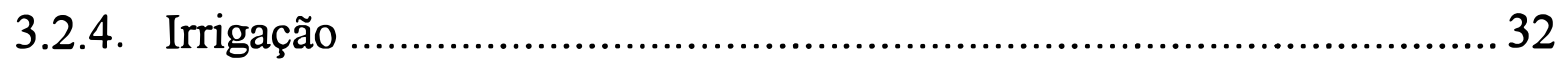

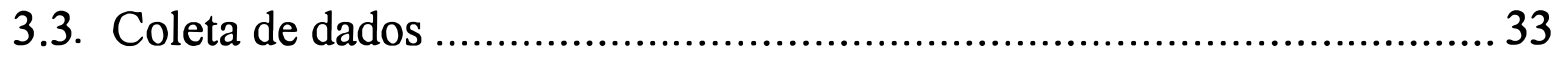

3.3.1. Dimensionamento do número de amostras......................................... 33

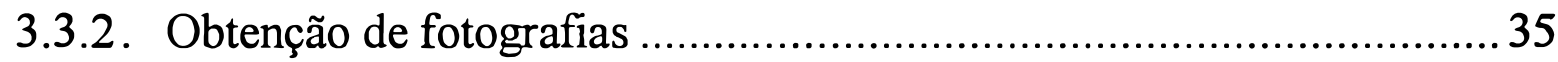

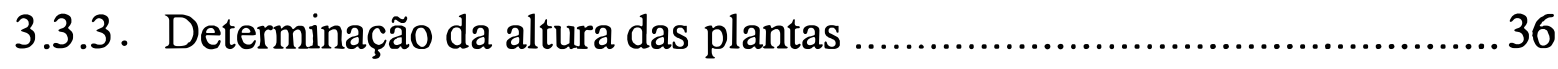

3.4. Processamento das fotografias ............................................................. 37

3.5. Processamento e análise estatística dos dados ......................................... 38

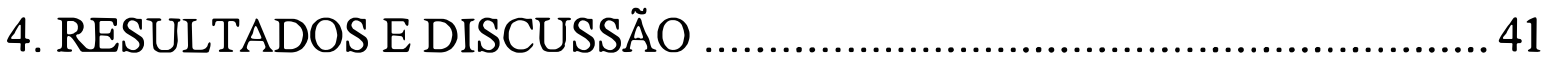

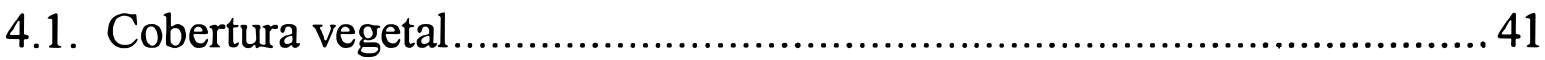

4.1.1. Variação na porcentagem de cobertura vegetal................................... 41

4.1.2. Redimensionamento do número de amostras ..................................... 44

4.1.3. Curva de evolução da cobertura vegetal em função do tempo

4.1.4. Períodos da cultura no processo erosivo …………............................ 51

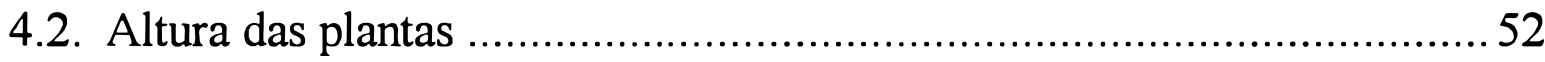


4.2.1. Variação na altura das plantas....................................................... 52

4.2.2. Redimensionamento do número de amostras .................................... 55

4.2.3. Curva de evolução da altura das plantas em função do tempo

4.2.4. Correlação entre a altura das plantas e a cobertura

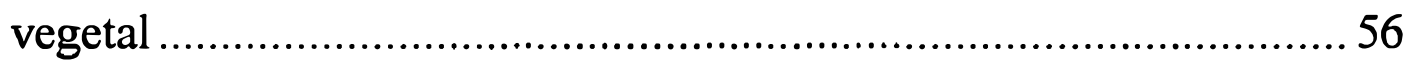

4.3. Considerações de ordem prática sobre a utilização do

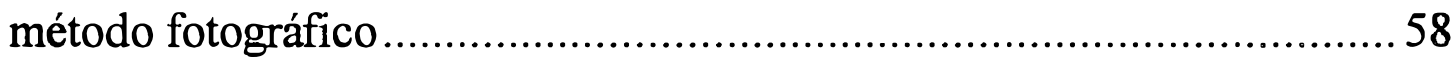

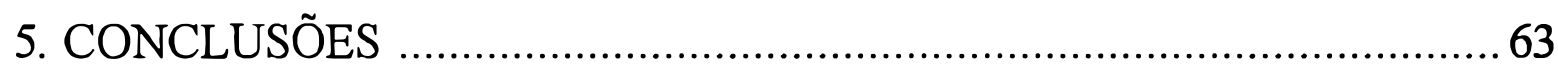

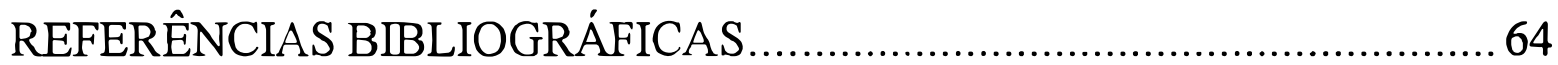




\title{
UTILIZAÇÃO DE FOTOGRAFIAS NA DETERMINAÇÃO DA PORCENTAGEM DE COBERTURA VEGETAL DO SOLO PELO MLHO (Zea mays)
}

\author{
Autor: JULIO RENÁN PANIAGUA ALCARAZ \\ Orientador: Prof. Dr. JÚLIO VASQUES FLHO
}

\section{RESUMO}

O presente trabalho teve por objetivos: (a) determinar o número mínimo de fotografias, ou a porcentagem da área total cultivada a ser amostrada, para se estimar a porcentagem média de cobertura vegetal em uma área cultivada com milho (Zea mays); (b) contribuir para a definição, para essa espécie, do nível de correlação existente entre a altura das plantas e a porcentagem de cobertura vegetal e da curva de evolução da porcentagem média de cobertura vegetal em função do tempo; e, (c) fazer uma avaliação dos materiais e técnicas utilizados no método fotográfico.

Para isso foi realizado um experimento, com stand de 55.000 plantas por hectare, numa gleba com área de $5.460 \mathrm{~m}^{2}$, pertencente ao Departamento de Agricultura, da Escola Superior de Agricultura "Luiz de Queiroz", da Universidade de São Paulo em Piracicaba-SP, localizada a $22^{\circ}$ $42^{\prime} 30^{\prime \prime} 9$ de latitude Sul, e 47 38'00" 8 de longitude a Oeste de Greenwich, e altitude de 576 metros acima do nível do mar. 
Durante todo o período de cultivo, foi procedida a coleta de dados, em cada uma das 36 quadrículas sorteadas e marcadas, da gleba considerada como sendo composta por 364 quadrículas iguais.

Para a obtenção das fotos foi utilizada uma máquina, operada por controle remoto eletrônico, sustentada a 5 metros acima da superficie do solo por uma estrutura metálica em forma de um L invertido. Para a análise da parte central das fotos foi utilizado o programa SIARCS, da EMBRAPA/CNPDIA, o qual dá valores da porcentagem de cobertura vegetal. A altura das plantas foi medida, em direção perpendicular à superficie do solo entre o colo da planta e o final da folha superior ou pendão no ápice de crescimento. A única planta medida, em cada uma das 36 quadrículas, foi aquela localizada à esquerda, a 1 metro da base do suporte da máquina fotográfica.

Os resultados obtidos nas condições do presente experimento permitem concluir que: (1) O método fotográfico teve sua viabilidade comprometida nos primeiros estádios da cultura,devido ao custo e consumo de tempo. (2) A altura das plantas, por requerer um número relativamente pequeno de amostras para a obtenção de valores médios, e por seu elevado coeficiente de correlação com a porcentagem de cobertura vegetal do solo representa uma alternativa promissora como parâmetro estimador dessa variável. (3) O material e as técnicas empregados no presente estudo aumentaram a eficiência do método fotográfico. (4) $\mathrm{O}$ método fotográfico tem sua eficiência aumentada em áreas com cobertura mais homogênea que permitam a utilização de pequenas áreas de amostragem. 


\title{
UTHLIZATION OF PHOTOGRAPHIES IN THE DETERMINATION OF MAIZE (Zea mays) VEGETAL COVERING
}

\author{
Author: JULIO RENÁN PANIAGUA ALCARAZ. \\ Advisor: JÚLIO VASQUES FILHO.
}

\section{SUMMARY}

The objetives of this study were: a) to determine the minimun number of pictures necessary, or the percentage of the total area to be sampled for estimating the average percentage of vegetative cover in an area cultivated with maize (Zea mays); b) to contribute to the definition, for this species, of the correlation's level between the plants height and the percentage of vegetal covering, and the average percentage of vegetal coverage evolution curve as a function of time; and, c) to evaluate the material and tecniques used in the method.

An experiment was carried out in an area of 5460 square meters at the department of Agriculture, Superior School of Agriculture "Luiz de Queiroz", University of São Paulo in Piracicaba-SP. The geographic location of the experimental area is $22^{\circ} 42^{\prime} 30^{\prime \prime} 9$ of South Latitude and $47^{\circ} 38^{\prime} 00^{\prime \prime} 8$ at the west of Greenwich meridian, at an altitude of 576 meters above the sea level.

The experimental plot was divided into 364 equal sized sampling squares. Data was periodically collected from 36 randomly selected sampling squares. 
To obtain the pictures, a camera, with an electronic remote control, was fixed to a L inverted metalic structure at 5 meters above the soil surface. The central part of the pictures were analized using the SIARCS software of EMBRAPA/CNPDIA which gives values of percentage vegetative coverage. The plant height was measured between its base and the top of the superior leaf or the tip of the tassel. Only one plant in each of the 36 marked sampling squares had its height measured. That plant was the one located one meter to the left of the metallic base structure.

The results permit to conclude that: (1) The viability of the photographic method was threatened in the first stages of maize growth due to increasing costs and time consumption. (2) Plant height is a promissory alternative as an estimating parameter of the average percentage of vegetative cover due to the fact that it requires a relatively small number of samples to get the mean values, and because of its high correlation with the percentage of soil vegetative cover. (3) The material and tecniques used in this study contribute to increment the efficiency of the photographic method. (4) The photographic method efficiency was increased in areas with homogeneous vegetative coverage, that permit the use of a little sampling area. 


\section{INTRODUÇĀO}

A cobertura vegetal do solo é um dos fatores mais eficientes na redução de sua erosão.

No processo de erosão pluvial, as plantas e os resíduos da colheita que ficam sobre o terreno interceptam as gotas de chuva e absorvem sua energia cinética, protegendo o solo contra a desagregação e o transporte de partículas pela chuva e pela enxurrada, reduzindo assim as perdas de terra. Quanto mais cobertura vegetal, menos erosão.

O aumento da cobertura vegetal influi, também, na diminuição do processo erosivo devido ao aumento do teor de matéria orgânica do solo, pelos efeitos desta no aumento da resistência do solo à erosão e na diminuição da compactação e encrostamento na sua superfície, cuja conseqüência é um aumento na infiltração de água no solo.

O milho é uma das 10 culturas dentre as quais ocorrem as maiores perdas de solo por erosão no Brasil, com estimativa de perda de 12 toneladas de solo por hectare (ocupando a décima posição) e de 5,2\% de água da chuva (ocupando a oitava posição) (Bertoni et al., 1972). A cultura do milho ocupa aproximadamente $33 \%$ das terras aráveis e $68 \%$ das terras ocupadas com cereais no Brasil (FAO, 1995). 
O fator C da Equação Universal de Perda de Solo identifica quantitativamente a participação do Uso e do Manejo do Solo no processo erosivo; requerendo para o seu cálculo, dentre outras, informações referentes à evolução, com o tempo, da porcentagem de cobertura do solo proporcionada pelas plantas cultivadas e seus resíduos. Um dos métodos empregados na análise do grau de cobertura utiliza o computador para o processamento de imagens fotográficas da cobertura do solo, recuperadas através de scanner.

As hipóteses do trabalho foram: (1) Sendo o número de amostras necessárias para se estimar a média de uma população diretamente proporcional à variabilidade dos dados do parâmetro estudado, logo o número de fotos necessárias para determinar a porcentagem de cobertura do solo é variável durante o ciclo da cultura, quando o desenvolvimento das plantas varia no espaço e no tempo; (2) Sendo o crescimento das plantas caracterizado pelo aumento de suas dimensões, logo haverá correlação entre o aumento da cobertura vegetal e o da altura das plantas com o tempo.

$\mathrm{O}$ presente trabalho teve por objetivos (1) determinar o número mínimo de fotografias, ou porcentagem da área total cultivada a ser amostrada, para se estimar a porcentagem média de cobertura vegetal em uma área cultivada com milho (Zea mays), (2) contribuir para a definição, para essa espécie, da curva de evolução da porcentagem média de cobertura vegetal em função do tempo, (3) do nível de correlação existente entre a altura das plantas e a percentagem de cobertura vegetal, e (4) fazer uma avaliação dos materiais e técnicas utilizados no método fotográfico neste estudo. 


\section{REVISÃO DE LITERATURA}

\subsection{Dimensionamento da cobertura vegetal no processo erosivo}

Segundo Wischmeier \& Smith (1978), a dimensão da participação da cobertura vegetal no processo erosivo é dada pelo fator (C) uso e manejo do solo da Equação Universal de Perda de Solo. Os efeitos das variáveis uso e manejo não podem ser avaliados independentemente devido às diversas interações que ocorrem entre os seus sub-fatores: Sistema de Preparo do Solo, Espécie Cultivada, Manejo dos Restos da Colheita e Efeito Residual do Uso Precedente.

Esse fator representa a relação existente entre as perdas de solo por erosão de um terreno cultivado segundo as recomendações de manejo utilizadas em dadas condições de uso, e as perdas de um terreno cultivado segundo as recomendações convencionais de manejo na cultura do milho ou do algodão, e mantido continuamente sem cobertura vegetal, ou morta, estando ambos os terrenos sob idênticas condições quanto aos demais fatores daquela equação. $\mathrm{O}$ fator $\mathrm{C}$ é, portanto, a expressão numérica da fração da erosão efetivamente ocorrida sob condições específicas de uso e manejo, tomando-se como referência a perda de solo ocorrida sob condições estabelecidas convencionalmente. $\mathrm{O}$ controle de erosão efetivamente 
manifestado sob condições específicas de uso e manejo, expresso em porcentagem como sendo igual a $100(1-C)$, resulta da conjunção da evolução da capacidade potencial de controle da erosão de tais condições, com a distribuição da capacidade erosiva da chuva, sendo a primeira dessas capacidades variável no tempo, de forma particular para cada espécie cultivada e para cada condição particular de manejo e a segunda variável no tempo e no espaço (Wischmeier \& Smith, 1978).

Face às múltiplas possibilidades de combinação entre as diversas condições de uso e manejo com as condições de erosividade de diversos locais, e com a finalidade de permitir a estimativa mais precisa do fator $\mathrm{C}$ para diferentes condições de uso e manejo e para diferentes localidades, a partir de resultados obtidos em um número limitado de locais, Wischmeier (1960) propôs, inicialmente, para o cálculo desse fator, que o ciclo das culturas fosse dividido em 5 períodos fixos de tempo. Entretanto, o aumento da cobertura do solo pelas plantas é gradual e se dá em uma série de períodos, nos quais a taxa de aumento da eficiência da ação integrada do uso e do manejo no controle da erosão pode ser considerada como constante, razão por que Wischmeier \& Smith (1978) passaram a definir esses períodos em função da porcentagem de cobertura vegetal, com durações variando de acordo com a cultura, o clima e o manejo. Esses mesmos autores consideram como sendo seis esses períodos, os quais são a seguir descritos: (1) Período F (preparo rústico ou primário), desde o preparo primário até o preparo secundário; (2) Período SB (sementeira), do final do período anterior até $10 \%$ de cobertura vegetal; (3) Período 1 (estabelecimento), do final do período anterior até $50 \%$ de cobertura vegetal (para o algodão até 35\%); (4) 
Período 2 (desenvolvimento), do final do período anterior até $75 \%$ de cobertura vegetal (60\% para algodão); (5) Período 3 (maturação) do final do período anterior até a colheita; (6) Período 4 (resíduos), da colheita até o início do novo preparo do solo ou plantio.

\subsection{Variação da distribuição da cobertura vegetal}

Mannering \& Johnson (1969) utilizaram o método fotográfico para comparar o efeito do espaçamento entre as linhas de plantio na cobertura vegetal e na erosão, nas culturas do milho e da soja, observando que com um espaçamento de 102 centímetros entre linhas a cultura do milho alcançou uma cobertura média máxima de aproximadamente $80 \%$ na oitava e nona semanas após a semeadura. Concluíram que, no caso do milho, nas condições desse experimento, embora para o espaçamento menor $(80 \mathrm{~cm}$.) tenham observado uma maior cobertura aparente depois do primeiro mês, 0 espaçamento entre as linhas não influenciou significativamente a cobertura vegetal.

Elwell \& Gardner (1976) relataram a ocorrência de uma alta variabilidade nos seus dados de altura das plantas e cobertura vegetal causados por baixa porcentagem de germinação das sementes utilizadas. Segundo Hartwig \& Laflen (1978), a maior fonte de variabilidade dos valores obtidos para a cobertura vegetal é a distribuição da cobertura e não o método de medição.

Elwell \& Wendelaar (1977) apresentaram três curvas típicas de crescimento da cobertura vegetal para o milho, algodão e fumo. Na curva do 
milho pode-se observar um crescimento lento até aproximadamente os 25 dias após a emergência, seguido de rápido crescimento até aproximadamente os 75 dias, quando é alcançada a cobertura máxima próxima de $95 \%$, que cai até valores próximos de $50 \%$ de cobertura, passados os 100 dias após a emergência. Uma curva de crescimento similar foi encontrada por Arruda (1984) para a cultura do milho com densidade de 70.000 plantas por hectare e não irrigado, atingindo a cobertura vegetal um valor máximo de aproximadamente $85 \%$, após o qual caiu para valores próximos a $60 \%$, passados os 100 dias após o plantio. Verificou-se que uma acentuada senescência das folhas pode, além de alterar a sua significância fisiológica, diminuir rapidamente o valor da cobertura vegetal por ser a cobertura vegetal composta também de folhas não ativas no processo produtivo da planta.

Sallaway et al. (1988) encontraram um desvio padrão entre 5 e 20 para dados de porcentagem de cobertura vegetal entre 30 e $70 \%$.

O coeficiente de variação para estimar a cobertura de resíduos, usando o método fotográfico, diminuiu, na medida que a cobertura aumentou de $20 \%$ para $99 \%$, nas três variantes do método de contagem de pontos estudados por Morrison et al. (1989).

De Maria (1995) apresentou períodos para a cultura de milho baseados no aumento da cobertura vegetal da variedade Maya, a qual atingiu $10 \%$ de cobertura aos 35 dias e $50 \%$ aos 60 dias após a semeadura, assim, o período SB foi limitado até os 35 dias, o período 1 até os 60 dias e o período 2 até os 80 dias após a semeadura; os demais períodos foram limitados por 
eventos e não por porcentagem de cobertura vegetal como sugerido por Wischmeier \& Smith (1978).

\subsection{A cultura do milho: ciclo vegetativo e aspectos fisiológicos}

O milho é uma planta anual, robusta, monocotiledonea, pertencente à família Graminae, à tribo Maydeae, e ao gênero Zea, sendo a espécie designada como Zea mays.

Para maior facilidade de estudo, o ciclo da cultura do milho foi dividido em 11 estádios distintos de crescimento perfeitamente reconhecíveis no campo. Os estádios de crescimento anteriores ao aparecimento das espigas, são identificados no campo mediante a avaliação do número de folhas plenamente emergidas, apresentando a linha de união, lâmina e bainha facilmente visíveis. Os estádios de crescimento após a ocorrência da espiga são identificados com base no desenvolvimento dos grãos (Gomes \& Karasawa, 1979).

A descrição dos estádios, assim como dos aspectos fisiológicos importantes, segundo Fancelli (1990), são apresentados a seguir.

Estádio 0 (do plantio à emergência): Não se observando a presença de nenhum fator inibitório no processo a germinação ocorre em 3 dias, a $18^{\circ} \mathrm{C}$. A maior influência na duração dessa etapa encontra-se relacionada com a profundidade de plantio, em função de que plântulas provenientes de semeaduras profundas emergem tardiamente. Uma semana após a emergência, a plântula apresenta-se com duas folhas totalmente emitidas, 
encontrando-se a partir desse ponto apta para iniciar o processo fotossintético.

Estádio 1 (planta com 4 folhas totalmente emergidas): coincide normalmente com a segunda semana após a emergência da planta, ocorrendo nesse período a diferenciação do meristema apical, cuja estrutura ainda se encontra abaixo da superfície do solo. Três semanas após a emergência, a região de crescimento atinge a superfície do solo.

Estádio 2 (planta apresentando 8 folhas): coincide freqüentemente com o primeiro mês após a emergência, caracterizando-se pelo crescimento do colmo em diâmetro e comprimento, e pelo inicio da formação da inflorescência masculina. Cinco semanas após a emergência, inicia-se o desenvolvimento das espigas no sexto ou oitavo nós acima do solo.

Estádio 3 (plantas com 12 folhas): relaciona-se à sexta semana após a emergência, sendo caracterizado pela máxima área foliar apresentada pela planta, embora apenas $85 \%$ das folhas formadas encontrem-se desenroladas. Ainda neste período, além da alta taxa de crescimento experimentada pelo colmo, pendão e espiga superior, ocorre também a perda das quatro folhas mais velhas, bem como o início de desenvolvimento das raízes adventícias a partir do primeiro nó, acima do solo.

Estádio 4 (plantas com 16 folhas): coincide normalmente com a nona semana após a emergência e caracteriza-se pelo aparecimento parcial do pendão ou flecha, pelo crescimento acentuado dos cabelos da espiga, bem como pela perda de 5 a 6 folhas basais da planta.

Estádio 5 (emergência dos estilo-estigmas e polinização): Na nona e décima semanas após a emergência das plantas inicia-se normalmente $o$ 
florescimento (com exposição dos "cabelos" das espigas), cessando as elongações do colmo e internódios.

Estádio 6 (grãos leitosos): ocorre 12 dias após o aparecimento dos "cabelos", caracterizando-se pelo início do processo de acumulação do amido no endosperma dos grãos, contribuindo assim para o incremento do seu peso seco. Tal aumento ocorre em grande parte devido à translocação dos sintetizados presentes nas folhas e no colmo para a espiga e grãos em formação. Neste período, em termos gerais, considera-se como importante caráter condicionador de produção, a extensão da área foliar que permanece fisiologicamente ativa após a emergência da espiga.

Estádio 7 (grão pastoso): neste estádio, 24 dias após a emissão do estilo-estigma, a deposição de amido é bastante acentuada, caracterizando um período destinado ao ganho de peso por parte do grão.

Estádio 8 (inicio da formação dos "dentes"): coincide normalmente com o trigésimo sexto dia após o aparecimento dos "cabelos", caracterizando-se pelo início da formação dos "dentes" na parte superior dos grãos, que encontram-se em fase de transição do estado pastoso para farináceo.

Estádio 9 (grãos "dentados"): Neste estádio, 48 dias após a emissão dos estilo-estigmas, todos os grãos encontram-se dentados, apresentando uma depressão característica em sua superfície superior, relacionada principalmente à acelerada perda de umidade evidenciada em toda a planta. Neste estádio ocorre a maduração morfológica do grão. 
Para cultivares de grão duro os estádios 8 e 9 tornam-se de difícil constatação no campo, podendo apenas serem relacionados ao aumento gradativo da dureza dos grãos.

Estádio 10 (grãos maduros fisiologicamente): ocorre normalmente 50 a 60 dias após a formação dos cabelos, evidenciando-se pela paralisação total do acúmulo de matéria seca no grão, coincidindo com o início do processo de senescência natural das folhas da planta, as quais gradativamente começam a perder a sua coloração verde característica. Este estádio é caracterizado pelo máximo peso seco dos grãos e máximo vigor da semente, é facilmente reconhecido no campo pela presença da "camada negra" formada no ponto de inserção do grão com o sabugo.

\subsection{Relação entre a porcentagem de cobertura vegetal e altura das plantas}

Wischmeier \& Smith (1978) apresentaram graficamente a relação de perdas entre um solo com e sem cobertura vegetal como função da ação integrada da altura das plantas e da porcentagem de cobertura vegetal do solo.

De Maria et al. (1989) encontraram uma alta correlação entre a cobertura vegetal do milho, medida através do método do cavalete com visores, e a altura das plantas. Outros parâmetros foram estudados e correlacionados com a cobertura vegetal, como por exemplo, a quantidade de resíduos segundo Sloneker \& Moldenhauer (1977). 


\subsection{Métodos utilizados para a determinação da porcentagem de cobertura do solo}

Segundo Adams \& Arkin (1977) o índice de área foliar não pode ser utilizado como um índice exato da cobertura vegetal, uma vez que esse parâmetro inclui todas as folhas da planta, muitas da quais não interceptam diretamente a luz solar nem as gotas da chuva, não podendo portanto serem consideradas como integrantes da cobertura vegetal no que concerne à participação das plantas no processo erosivo.

A porcentagem da superfície de solo, que está coberta por resíduos ou plantas, pode ser estimada qualitativamente segundo julgamento arbitrário de um observador, sendo a subjetividade a maior desvantagem deste método. Idealmente, a porcentagem de cobertura vegetal deveria ser determinada por medição direta da área coberta em relação à área total do solo (Corak et al., 1993).

A seguir são apresentados os métodos mais comuns de avaliação da cobertura vegetal.

\subsubsection{Método da régua métrica}

Consiste em se colocar uma régua métrica na superfície do solo, perpendicularmente a duas linhas de plantas contíguas, para medir, linearmente, ao longo dessa régua e sob ela, o total de terreno coberto por resíduos de plantas. A cobertura de resíduos é calculada dividindo-se o valor assim obtido pelo espaço entre as linhas de plantas. $\mathrm{O}$ método se presta tanto 
para avaliar a cobertura de resíduos na superfície do solo, como a cobertura por plantas, através da medida de suas sombras projetadas na superfície do solo (Adams \& Arkin, 1977 e Hartwig \& Laflen, 1978).

Andrade \& Ocumpaugh (1979) construíram um aparelho para medir a cobertura vegetal, denominado "transector", que utiliza os mesmos princípios do método da régua métrica. Este aparelho apresenta uma primeira haste horizontal, que é fixa e tem 5,3 metros de comprimento, sustentando uma segunda haste, que é milimetrada e tem 1,2 metros, sobre a qual é montada uma terceira haste. A segunda e a terceira hastes são equipadas com um pino cada uma em seus respectivos lados esquerdos, onde se localiza o início da escala da segunda haste, e deslizam sobre a haste maior. O aparelho é sustentado por dois pés localizados em cada extremo da haste maior. A leitura da cobertura vegetal do solo é feita colocando-se os pinos em cada extremo de uma linha imaginária que passa sobre a porção de vegetação a ser medida, e que tem o comprimento dessa porção, o qual é anotado para posterior transformação em porcentagem.

\subsubsection{Método do cavalete com visores}

Segundo Elwell \& Gardner (1976) este método já foi descrito por Cackett $^{1}$ (1964), e depois por Stocking² (1972).

O equipamento consiste de uma barra horizontal com dez orifícios de 2 milímetros de diâmetro, posicionada 30 centímetros acima de uma barra

${ }^{1}$ CACKETT, K. F.. A simple device for measuring canopy cover. Rhodesian Journal Agriculture Research, 2 (1): 56 - 57, 1964.

${ }^{2}$ STOCKING, M. A.. A geographical analysis of the factors in the erosion of soils in Rhodesia. Londres, 1972. Tese (Master Phil ) - University of London. 
horizontal com dez orifícios de 1 milímetro de diâmetro, sustentadas em posição paralela por um cavalete, de modo que os orifícios com posições correspondentes nas barras tenham disposição concêntrica e a barra inferior fique a 1,25 metros de distância do chão. Para operar o aparelho, o observador mira verticalmente através de um par de orifícios situados nas barras superior e inferior. Se é avistado solo nú, o observador registra "0". Se é avistada vegetação, registra "1" (Elwell \& Gardner, 1976). A porcentagem de cobertura do solo é calculada dividindo-se por 10 a soma do número de leituras com registro igual a " 1 " e multiplicando-se o resultado por 100. Para culturas que ultrapassam 1,25 metros de altura existe um aparelho modificado que utiliza um conjunto de espelhos colocado obliquamente, de forma a permitir a observação da imagem refletida das folhas da cultura contrastadas com o céu (Elwell \& Gardner, 1976).

\subsubsection{Método da corda com marcas}

Van Doren Jr. ${ }^{3}$, citado por Sloneker \& Moldenhauer (1977) descreveu o método da corda com marcas. É um método similar ao descrito por Laflen et al. (1981). Consiste em se esticar uma corda, previamente marcada a intervalos predeterminados, e fazer as observações de forma semelhante à que se faz no método do cavalete, ou seja apontando " 0 " se o solo abaixo da marcação estiver sem cobertura, e "1", se o solo abaixo estiver com cobertura. A desvantagem deste método é que somente pode ser utilizado com cobertura morta ou cobertura próxima da superfície do solo.

\footnotetext{
3VAN DOREN Jr., D. M. (Wooster, Ohio). Correspondência pessoal, 1977.
} 
As limitações deste método, destacando-se dentre elas sua subjetividade, uma vez que a posição do observador e conseqüentemente o ângulo de visão são influenciados pela presença de resíduos próximos da corda, aumentam quando ele é utilizado em culturas de altura variável quando, então, a cobertura vegetal é superestimada (Laflen et al., 1981).

Pierson et al. (1988) estudaram a exatidão de um número baixo de observações relacionado à experiência dos observadores e concluíram que existe diferença significativa entre observadores experimentados e não experimentados e que essa diferença diminuiu na medida em que aumentou o número de observações.

\subsubsection{Método da intercepção da luz}

Segundo Adams \& Arkin (1977), a estimativa da porcentagem de cobertura vegetal do solo pelo método da intercepção de luz é feita determinando-se a porcentagem da superfície do solo sombreada pela cobertura vegetal, e a melhor hora para se empregar este método, é ao meio dia, quando o ângulo formado entre a luz solar e a superfície da terra é de $90^{\circ}$. Para a medição da intercepção de luz, esses autores utilizaram protótipos, ainda não encontrados no comércio, de dois tipos de aparelhos: o "spatial quantum sensor" (SQS), e o "traversing quantum sensor", que calculam a cobertura vegetal por transmissão de luz através de um sensor. 


\subsubsection{Método da largura do dossel vegetativo}

Consiste na medição da largura da cobertura vegetal, compreendida entre os pontos mais extremos das folhagens, rigorosamente a intervalos de 10 centímetros, controlados por uma régua de 100 centímetros colocada na superfície do solo, paralelamente à linha de plantio. $\mathrm{O}$ cálculo da cobertura é obtida por:

$$
\% C V=\frac{L \cdot 100}{e}
$$

onde: $\% C V$ é a percentagem de cobertura vegetal, $L$ é a largura média do dossel em centímetros, e e é o espaçamento entre as linhas de plantio em centímetros (Arruda, 1984). No mesmo trabalho, esse método, em comparação com outros métodos de medição da porcentagem de cobertura vegetal, mostrou-se relativamente fácil, rápido, barato e com a vantagem de não depender da presença de radiação direta ou de horário para as medições. Porém, esse método tendo como pressuposto uma completa cobertura do solo dentro da linha de plantio, é adequado às culturas de plantas de folhas largas e com plantio relativamente denso dentro da linha, não sendo, portanto, apropriado para a cultura de milho. 


\subsubsection{Métodos iconográficos}

Segundo Wimbush et al. (1967) e Goodwin \& Walker ${ }^{4}$, citados por Elwell \& Gardner (1976), fotografias em preto e branco e coloridas da superfície do solo tem sido utilizadas na coleta de dados sobre a composição de espécies da vegetação, e na determinação da porcentagem de cobertura vegetal com o auxílio da estereoscopia.

Segundo Elwell \& Gardner (1976) fotografias aéreas têm sido utilizadas com uma grande diversidade de objetivos. Além disso, fotografias aéreas verticais (tiradas de satélite ou de avião) são utilizadas comumente como auxilio no planejamento de uso da terra.

Sloneker \& Moldenhauer (1977), Meyer et al. (1988) e Morrison et al. (1989) citaram a utilização de imagens procedentes de diafilmes para a avaliação da cobertura vegetal do solo.

Meyer et al. (1988), Morrison \& Chichester (1991) e Corak et al. (1993) analisaram imagens de vídeo.

Meyer et al. (1988) analisaram imagens em preto e branco e em cores, e concluíram que o sistema de transferência de vídeo para o computador apresentou melhor as cores para o computador, embora com a utilização de diafilmes tivesse sido obtida uma resolução espacial maior.

Segundo Arruda (1984) o método fotográfico, com número limitado de medições realizadas, apresentou erros consideráveis na fase inicial das culturas do milho e feijão, em momentos em que nenhum dos outros métodos

\footnotetext{
${ }^{4}$ GOODWIN, W. F.; WALKER, J.. Photographic recording of vegetation in regeneration woodland. Technical Comunication No. 1. Woodland Ecology Unit CSIRO, 1972.
} 
mostrou a menor viabilidade de uso, sendo no caso de plantios a lanço ou de densidade alta, talvez um dos únicos métodos disponíveis.

\subsubsection{Obtenção das imagens}

No método fotográfico para avaliação da porcentagem de cobertura vegetal a imagem é obtida de uma fotografia tirada, por controle remoto, perpendicularmente à superfície do terreno, com a câmara suspensa, numa estrutura metálica móvel, utilizando-se filme colorido convencional (Elwell \& Wendelaar, 1977 e Jong Van Lier et al., 1993).

Segundo Vasques Filhos (1995) o transporte da estrutura metálica construída com tubos de ferro galvanizado e sem articulações, só pôde ser realizado por um trator ou camioneta.

Fotografias obtidas de alturas de 1 metro (Meyer et al. 1988), 1,5 metros (Williams, 1979 e Arruda, 1984), 5 metros (Sallaway et al., 1988), 6 a 8 metros (Jong Van Lier et al., 1993) acima da superfície do solo, foram utilizadas para a avaliação da cobertura vegetal.

Morrison et al. (1989) tiraram fotografias com uma câmara equipada com uma lente de 50 milímetros, posicionada verticalmente acima do solo a distâncias de 1; 1,5 e 2 metros. O efeito da altura da câmara na estimativa da cobertura, que não foi observado no caso de resíduos localizados até 25 centímetros acima da superfície do solo, foi significativo no caso de resíduos localizados acima de 60 centímetros.

\footnotetext{
5VASQUES FILHO, J. (Escola Superior de Agricultura "Luiz de Queiroz"/USP, Piracicaba, SP) Comunicaçao pessoal, 1995.
} 
Elwell \& Wendelaar (1977) afirmaram que o método fotográfico não provoca danos à cultura durante a sua utilização, e que o movimento das folhas devido ao vento não é um problema considerável.

Elwell \& Gardner (1976) propuseram a utilização de uma fonte de luz adicional mais potente do que o "flash" da máquina fotográfica. Meyer et al. (1988) sugeriram a cobertura da área a ser fotografada a fim de evitar a incidencia da luz solar direta e a utilização de um "flash" eletrônico, mais potente, para dar luz tanto em dias nublados como em dias ensolarados. Thomas et al. (1988) concluíram que uma pobre iluminação poderia ser a causa da dificuldade para avaliar a cobertura vegetal em fotografias com baixo contraste entre o solo e as folhas, por meio da análise digital das imagens pelo computador.

Adams \& Arkin (1977) e Arruda (1984) relataram que o método fotográfico pode ser usado tanto com céu nublado como descoberto.

\subsubsection{Análise das imagens}

A partir das fotografias reveladas foram desenvolvidos diversos métodos com a finalidade de avaliar a porcentagem ocupada na foto pela imagem fotográfica da cobertura vegetal, sendo o mais comum aquele que faz uma avaliação estatística da cobertura pela leitura de uma malha regular de pontos de observação colocada sobre a foto (Hartwig \& Laflen, 1978 e Jorge et al., 1993). 
Elwell \& Gardner (1976) avaliaram a cobertura vegetal do solo mediante a superposição, na fotografia, de uma transparência com 86 pontos distribuídos ao acaso.

Sloneker \& Moldenhauer (1977) citaram a utilização de um método para medir a cobertura de resíduos por meio do densitômetro. Segundo Lowery et al. (1984), o densitômetro mede a densidade do filme pela quantidade de iluminação que o atravessa, o que depende da opacidade da imagem; quanto mais escura a imagem, menor a quantidade de luz que atravessa o filme e maior sua densidade.

Arruda (1984) processou as fotografias, para determinar a porcentagem de cobertura vegetal, por meio de um planímetro.

Meyer et al. (1988) concluíram que o sistema com imagens coloridas funcionou melhor do que o sistema com imagens em preto e branco e, que a classificação dos resíduos, via computador, forneceu resultados mais exatos do que o método manual de contagem de pontos.

Thomas et al. (1988) desenvolveram um procedimento de processamento de imagens por computador, que utiliza a área total da fotografia e dá melhores resultados do que o método de contagem de pontos.

Morrison et al. (1989) utilizando a projeção de diafilmes, concluíram que a tela de projeção com pontos é mais apropriada para comparação de tratamentos do que para a determinação de valores absolutos de cobertura por resíduos.

Han \& Hayes (1990), desenvolveram um método para analisar imagens fotográficas de cobertura do solo usando a diferença entre as cores da imagem fotográfica do solo e a dos resíduos e das plantas. O método 
apresenta as vantagens de ser rápido, exato e com menores erros humanos, em comparação com o método que utiliza uma rede quadriculada sobre as fotografias.

Morrison \& Chichester (1991) relataram a calibração e o desenvolvimento de um procedimento para a determinação da porcentagem de área do solo com cobertura de resíduos a partir de imagens de vídeo e concluíram que basta que se analise apenas $12 \%$ dos pixels da imagem para a obtenção de resultados estáveis.

Em um outro método, a imagem fotográfica da cobertura vegetal é transcrita manualmente para um papel vegetal colocado sobre a foto, sendo, a seguir, a imagem em preto e branco no papel transferida, pelo emprego de um "scanner", para a tela de um microcomputador, onde é preparada para ser processada segundo um programa para cálculo da porcentagem de cobertura (Jong Van Lier et al., 1993).

Corak et al. (1993) testaram diversos métodos de análise de imagens de cobertura vegetal do solo. Os métodos testados foram: o método da transcrição de imagens para transparências, para transferência por "scanner" para análise por computador; o método de amostragem de pontos; o método de projeção de diafilmes numa tela com pontos; os métodos dos quadriculados de 2,5 e 5 centímetros de malha; e a análise de imagens obtidas com uma câmara de vídeo. Os resultados encontrados mostraram que determinações feitas com o primeiro e o terceiro métodos citados não foram significativamente diferentes e que o método de análise de imagens obtidas com uma câmara de vídeo superestimou a cobertura com resíduos. 


\subsubsection{Amostragem}

Segundo Elwell \& Gardner (1976) na determinação da porcentagem de cobertura vegetal do solo o número de observações requeridas decresce na medida que aumenta a uniformidade da cobertura e diminui o grau de precisão requerido. Esses mesmos autores, testaram o método fotográfico e o do cavalete com visores, utilizando 30 pontos de amostragem para duas alturas de planta da cultura de girassol, e concluíram que o número de observações requerida para obter uma precisão de $5 \%$ a mais ou a menos da média, foi de 41 e 75 para o método do cavalete com visores, e de 31 e 33 para o método fotográfico, respectivamente, para a menor e a maior alturas.

Segundo Hartwig \& Laflen (1978), utlizando o método da régua métrica, foram necessárias 12 medidas para reduzir o intervalo de confiança a $25 \%$ da média de cobertura por resíduos.

Williams (1979) analisou a porcentagem de erro do método fotográfico e concluiu que o grau de erro, é relacionado à estrutura da planta em culturas com plantas isoladas, sendo mínimo em culturas densas. Esse mesmo autor apontou que o erro pode ser reduzido usando-se só a porção central da fotografia (reduzindo-se o ângulo de visão da câmara) ou mediante o uso de uma lente com grande distância focal, e apresentou uma fómula onde é calculada a área coberta como sendo uma circunferência de rádio $R$ que é função da altura da câmara acima do solo $(H)$ e da tangente do ângulo $(\theta)$ de visão da câmara.

Assim: 


$$
R=H \cdot \operatorname{tg} \theta
$$

Laflen et al. (1981) estimaram em 15 observações o número mínimo para atingir uma precisão de $\pm 15 \%$ da média da cobertura por resíduos utilizando os métodos fotográfico e da régua métrica.

Curram \& Williamson ${ }^{6}$ citados por Pierson et al. (1988) concluíram que o número de observações necessárias aumenta na medida que o tamanho da área e a sua variabilidade aumentam.

Utilizando o método fotográfico para medir a cobertura do solo por resíduos de culturas, Pereira et al. (1986) concluíram que para porcentagens de cobertura superiores a 50\% foram necessárias pelo menos 15 determinações para que este método fornecesse resultados médios satisfatórios e Sallaway et al. (1988) constataram que o número de amostras necessárias, para se atingir uma média com 5 pontos percentuais a mais ou a menos, foi de 24 fotografias.

Segundo o Grupo de Reelaboração do Ensino de Física (GREF) (1991), tomando em consideração as relações da Figura 1, o tamanho da área fotografada depende da distância focal da lente $(F)$, do tamanho do filme $\left(t_{x} e\right.$ $t_{y}$ ) e da distância entre o objeto e a lente (d). Como os ângulos, formados nos triângulos da Figura 1, são iguais (opostos pelo vértice), para o comprimento da fotografia, pode-se estabelecer a relação:

$$
a_{x}=\frac{t_{x}}{F} \cdot d
$$

\footnotetext{
${ }^{6}$ CURRAN. P. J.; WILLIAMSON, H. D.. The accuracy of ground data used in remote sensing investigations. International Journal remote Sensing, v. 6, f. 10,1637-51, 1985.
} 
onde $a_{x}$ é o comprimento da área fotografada, e $t_{x}$ é o comprimento do negativo.

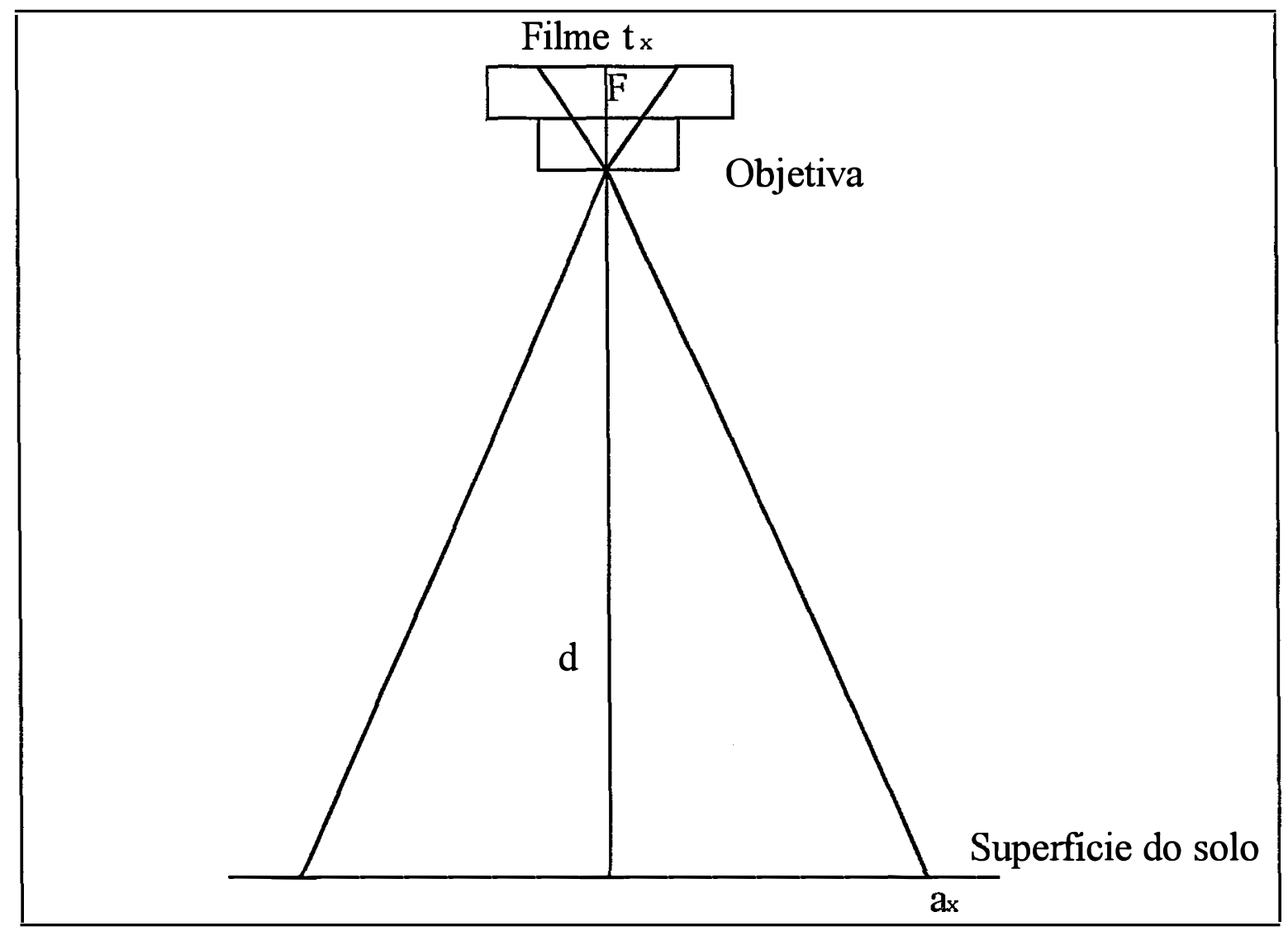

Figura 1. Esquema representando as relações entre a máquina fotográfica e a área fotografada.

Analogamente para a largura da área fotografada temos:

$$
a_{y}=\frac{t_{y}}{F} \cdot d
$$

sendo $a_{y}$ a largura da área fotografada e $t_{y}$ a largura do negativo.

Como a área $(A)$ de um retângulo (área da fotografia) é definida pelo produto da largura vezes o comprimento, temos: 


$$
A=a_{x} \cdot a_{y}
$$

Lowery et al. (1984) encontraram que a área coberta por uma fotografia, tomada com uma máquina fotográfica de 50 milímetros de distância focal, e posicionada a 1,5 metros acima da superfície do solo, foi de 0,72 metros de largura por 1,10 metros de comprimento.

Meyer et al. (1988) apresentam dados de área de 0,76 metros de largura por 1,20 metros de compnimento, coberta por uma fotografia tirada com uma máquina fotográfica com lente de distância focal de 28 milímetros, posicionada 1 metro acima da superfície do solo.

A área coberta por cada fotografia, tirada a 5 metros de altura foi de 2,3 metros de comprimento por 1,8 metros de largura (Sallaway et al., 1988).

Corak et al. (1993) fotografaram uma área de 76 centímetros de comprimento por 52 centímetros de largura usando uma máquina fotográfica de 55 milímetros de distância focal, suspensa a uma altura de 1,3 metros acima da superfície do solo.

\subsubsection{Eficiência}

Segundo Elwell \& Gardner (1976) a técnica fotográfica envolve um custo inicial alto (câmara fotográfica, filme e processo de revelação), além da necessidade de dois operários e de uma camioneta ou trator, respectivamente, para o manejo e o transporte da estrutura metálica de sustentação da câmara fotográfica. Esses mesmos autores utilizaram em 
média um tempo de 6,23 minutos para o processamento das fotografias da cobertura vegetal.

O uso do método fotográfico fornece observações permanentes, reduz o tempo de observação no campo, e é viável mesmo nos dias em que há movimentação da vegetação, provocada pelo vento. Contudo, a distorção da imagem fotográfica, que aumenta do centro para as bordas da foto, limitando sua área útil; a necessidade de que a câmara fotográfica seja elevada a mais de 20 metros do solo, quando utilizado para culturas em linhas com altura maior do que 0,50 metros; e a possibilidade de perda de dados por falhas na câmara fotográfica ou no processamento das fotos são apontadas como suas limitações por Elwell \& Wendelaar (1977) e Hartwig \& Laflen (1978).

Arruda (1984) utilizou um tempo de processamento das imagens fotográficas de 30 minutos. Lowery et al. (1984) determinaram o tempo de processamento de uma imagem fotográfica em 4,7;1,9 e 3,8 minutos com a utilização de malhas quadriculadas de 726, 500 e 529 pontos de interseção respectivamente. Com essa mesma metodologia, Morrison et al. (1989) utilizaram pelo menos 20 minutos para analisar uma fotografia de cobertura por resíduos e consideraram que o método é cansativo e sujeito, com o decorrer do tempo, à introdução de maior quantidade de erros humanos por causa da fatiga.

Cogo \& Amado (1986), em condições controladas de laboratório, avaliaram a exatidão do método fotográfico na determinação da porcentagem de cobertura do solo por resíduos culturais. Os valores de cobertura estimados por esses autores apresentaram correlação elevada com os valores 
reais $(\mathrm{r}=0,99)$ ao nível de $1 \%$ de probabilidade, o que indica a elevada exatidão do método.

Segundo Han \& Hayes (1990) os métodos de processamento de imagens e o de malha regular de pontos, produzem resultados similares, e a correlação entre ambos é alta $(\mathrm{r}=0,96)$. Esses mesmos autores concluíram que pesquisas adicionais são necessárias para determinar o tamanho da subimagem e a resolução espacial a serem utilizadas, o que poderia reduzir o tempo de processamento das fotografias.

O procedimento de análise de imagens de vídeo requer no máximo 2 minutos para cada imagem, uma vez que elimina a necessidade de revelar a fita para a avaliação (Morrison \& Chichester, 1991).

Corak et al. (1993) utilizaram em média 39 minutos para realizar a demarcação da imagem fotográfica em transparências, a seguir analisada por diferentes métodos: análise de imagens por computador, medidor de área foliar, contagem de pontos (100, 200 e 400 pontos), no que gastaram em média $\geq 1 ; \geq 1 ; 4 ; 4,5$ e 7 minutos, respectivamente, para sua avaliação final.

A digitalização e o processamento da imagem torna o cálculo da porcentagem de cobertura do solo por culturas mais automático e mais preciso (Jorge et al., 1993).

A obtenção das fotografias, segundo Arruda (1984) e Sallaway et al. (1988), pode ser facilmente realizada por um operário.

Williams (1979) constatou que cinco fotografias poderiam ser obtidas em 2 minutos, enquanto para Jong Van Lier et al. (1993) o rendimento da obtenção de fotografias é de aproximadamente de 20 fotografias por hora, ou seja, 3 minutos por fotografia. 
2.5.6.5. Comparação entre o método fotográfico e outros métodos de determinação da cobertura vegetal do solo

Elwell \& Gardner (1976) testaram os métodos fotográfico e do cavalete com visores para avaliação da cobertura vegetal em dois estádios da cultura de girassol, identificados pela altura da planta de 0,2 e 0,6 metros, utilizando 30 pontos de amostragem para cada estádio e concluíram que a diferença foi mínima na estimativa da cobertura vegetal pelas duas metodologias para a altura menor; no entanto, o método fotográfico superestimou a cobertura vegetal no estádio correspondente às plantas mais altas.

Sloneker \& Moldenhauer (1977) observaram que é alta a correlação entre o método fotográfico e o método da corda com marcas na determinação da porcentagem de cobertura do solo por resíduos. Alem disso, encontraram alta correlação, também, entre a porcentagem de cobertura por resíduos determinada pelo método fotográfico e a quantidade de resíduos para três culturas.

Adams \& Arkin (1977) compararam os valores da porcentagem de cobertura vegetal do solo, de cinco espécies de plantas, determinados pelos métodos: fotográfico, régua métrica e "Spatial Quantum Sensor". Embora os valores obtidos pelo método fotográfico tenham sido ligeiramente maiores, a análise estatística demonstrou que as diferenças entre valores de cobertura vegetal determinados pelos três métodos não foram significativas ao nível de $5 \%$. 
O método da régua métrica produz resultados ligeiramente inferiores aos obtidos com o método fotográfico em alta densidade de resíduos, embora esses resultados apresentem correlação elevada $(\mathrm{r}=0,88)$ entre eles (Hartwig \& Laflen, 1978).

Laflen et al. (1981) comparando o método da corda com marcas e os métodos fotográfico e da régua métrica, verificaram que o primeiro atinge maior precisão com 5 determinações, do que os outros dois métodos com 15 , concluindo ser o método da corda com marcas o mais preciso.

Arruda (1984) estudou cinco atributos de quatro métodos de estimativa da cobertura vegetal como apresentados na Tabela 1.

Pereira et al. (1986) compararam o método fotográfico e o método da régua métrica, e concluíram que o primeiro é melhor do que o segundo na medição de cobertura por resíduos de culturas. 
Tabela 1. Atributos de quatro métodos de estimativa da cobertura vegetal de diferentes culturas.

\begin{tabular}{|c|c|c|c|c|}
\hline \multirow[b]{2}{*}{ Atributo } & \multicolumn{4}{|c|}{ Métodos } \\
\hline & Fotográfico & Sensor 7 & $\begin{array}{l}\text { Régua } \\
\text { métrica }\end{array}$ & $\begin{array}{l}\text { Largura } \\
\text { do dosse }\end{array}$ \\
\hline $\begin{array}{l}\text { Obtenção de dados } \\
\text { no campo }\end{array}$ & $\begin{array}{c}\text { Fácil } \\
(1-2 \mathrm{~min})\end{array}$ & $\begin{array}{l}\text { Médio } \\
\text { (3 min) }\end{array}$ & $\begin{array}{l}\text { Complicado } \\
(15-20 \min )\end{array}$ & $\begin{array}{l}\text { Médio } \\
(10 \mathrm{~min})\end{array}$ \\
\hline $\begin{array}{l}\text { Dificuldade para um } \\
\text { operador no campo }\end{array}$ & Fácil & Média & Difícil & Média \\
\hline $\begin{array}{l}\text { Processamento dos } \\
\text { dados no escritório }\end{array}$ & $\begin{array}{l}\text { Complicado } \\
\text { (30 min) }\end{array}$ & $\begin{array}{l}\text { Fácil } \\
(3 \mathrm{~s})\end{array}$ & $\begin{array}{l}\text { Médio } \\
(60 \mathrm{~s})\end{array}$ & $\begin{array}{l}\text { Fácil } \\
(15 \mathrm{~s})\end{array}$ \\
\hline Condições especiais & Não & $\begin{array}{l}\text { Dia } \\
\text { claro }\end{array}$ & $\begin{array}{l}\text { Radiação } \\
\text { direta, sem } \\
\text { vento forte }\end{array}$ & $\begin{array}{l}\text { Plantio } \\
\text { denso }\end{array}$ \\
\hline Tipo de cultura & $\begin{array}{l}\text { Porte não } \\
\text { elevado }\end{array}$ & $\begin{array}{c}\mathrm{A} \\
\text { maioria }\end{array}$ & Em linha & Em linha \\
\hline Custo & Médio & Alto & Barato & Barato \\
\hline
\end{tabular}

Fonte: Arruda (1984)

${ }^{7}$ Refere-se ao método de intercepção de luz.

${ }^{8}$ Refere-se ao tempo para a obtenção dos resultados em uma parcela experimental, com três medições. 


\section{MATERIAL E MÉTODOS}

\subsection{Caracterização do local do experimento}

Foi montado um experimento de campo nurna gleba pertencente ao Departamento de Agricultura, da Escola Superior de Agricultura "Luiz de Queiroz", da Universidade de São Paulo, em Piracicaba, Estado de São Paulo, localizada a $22^{\circ} 42^{\prime} 30^{\prime \prime} 9$ de latitude Sul, e $47^{\circ} 38^{\prime} 00^{\prime \prime} 8$ de longitude a Oeste de Greenwich, e altitude de 576 metros sobre o nível do mar.

Essa gleba, de 5460 metros quadrados, se caracteriza por apresentar solo classificado como Terra Roxa Estruturada Latossólica eutrófica, A moderado, textura argilosa/muito argilosa (Kandiudalf Eutrudox); relevo plano com 1 a $2 \%$ de declividade; relevo regional ondulado a forte ondulado; ausência de processo erosivo significativo; ausência de pedregosidade e de rochosidade; drenagem moderada a boa; e uso atual com culturas anuais (Vidal-Torrado et al. ${ }^{9}, 1993$ ).

O clima da região, classificado de acordo com o sistema de Köppen, é do tipo Cwa, mesotérmico úmido subtropical de inverno seco. A vegetação natural original pertenceu ao subtipo floresta latifoliada tropical (Ranzani et

9VIDAL-TORRADO, P.; SPAROVEK, G.; COOPER, M.; OLIVEIRA, M. C. Mapa pedológico detalhado do Campus "Luiz de Queiroz". Escola Superior de Agricultura Luiz de Queiroz. 1993. Não publicado. 
al., 1966). Segundo Bertoni e Lombardi Neto (1990) a erosividade anual média da chuva na região é em torno de $6.500 \mathrm{Mj} . \mathrm{mm} / \mathrm{ha}$.h, com a seguinte distribuição percentual cumulativa mensal, iniciada com $0 \%$ em 10 de julho: $1 \%, 2 \%, 4 \%, 12 \%, 42 \%, 65 \%, 84 \%, 95 \%, 97 \%, 100 \%$.

\subsection{Manejo do sistema produtivo}

Com a colaboração do Grupo de Experimentação Agropecuária (GEA), do Departamento de Agricultura da ESALQ foram realizados os trabalhos de campo, a seguir descritos.

\subsubsection{Preparo do solo, aplicação de herbicida e semeadura}

O preparo do solo foi realizado nos dias 1 e 2 de novembro de 1995 e consistiu de uma aração e uma gradagem com grade leve. No dia 3 foi aplicado o herbicida Primextra (Atrazina + Metolachlor) em dose de 5 litros por hectare.

No dia 6 procedeu-se à semeadura do híbrido triplo de milho de ciclo normal, XL-380, da BRASKALB, tendo sido usada quantidade de semente necessária para obtenção de uma população de 55.000 plantas por hectare, com 5,5 plantas por metro linear e espaçamento de 1 metro nas entrelinhas (Braskalb, 1996). 


\subsubsection{Adubação}

A adubação foi realizada com base na análise do solo da gleba. No plantio foram aplicados 220 quilogramas por hectare de MAP (Fosfato monoamônico), e em 3 e 20 de dezembro de 1995, e 10 de janeiro de 1996, foram aplicados 90 e 105 quilogramas por hectare de Uréia, e 330 quilogramas por hectare de Sulfato de Amônio, respectivamente.

\subsubsection{Tratamento fitossanitário}

A cultura foi tratada com Decis (Deltametrina) e Lorsban (Clorpirifos etil) contra o ataque de insetos, em doses de 200 e 400 mililitros por hectare, respectivamente, em três oportunidades, nos dias 6 de novembro, 3 e 7 de dezembro de 1995.

\subsubsection{Irrigação}

Foi instalado um sistema de irrigação com distância de 9 metros entre as linhas de aspersores e entre os aspersores, de forma a suprir as necessidades de água da cultura em períodos críticos. 


\subsection{Coleta de dados}

\subsubsection{Dimensionamento do número de amostras}

Para o cálculo da área fotografada, foi adotada a Eq. (5) utilizada pelo GREF (1991), na qual foram inseridos os dados correspondentes à distância focal da lente da máquina fotográfica, igual a 0,038 metros, ao comprimento e à largura do negativo, iguais a 0,036 e 0,024 metros, respectivamente. Assim:

$$
\begin{aligned}
& a_{x}=\frac{0,036 \times 5}{0,038}=4,74 \\
& a_{y}=\frac{0,024 \times 5}{0,038}=3,16 \\
& A=4,74 \times 3,16=14,98 \cong 15 \mathrm{~m}^{2}
\end{aligned}
$$

Sendo de 15 metros quadrados ( $3 \times 5$ metros) a área de cada parcela, correspondente a uma fotografia, obteve-se uma área total fotografada a cada ICD $(36 \times 15)$ de 540 metros quadrados correspondendo a $9,8 \%$ da área total do experimento, para o primeiro dimensionamento da amostra, sendo esse um valor muito próximo dos $10 \%$ da área total recomendada por Campos ${ }^{10}$ (1996).

Durante todo o período de cultivo, desde a fase de germinação até a de colheita, a cada Intervalo de Coleta de Dados (ICD) que variou entre 5 e

\footnotetext{
${ }^{10}$ CAMPOS, H. De. (Escola Superior de Agricultura "Luiz de Queiroz"/USP, Piracicaba, SP) Comunicação pessoal, 1996.
} 
15 dias, foi procedida a coleta de dados, a qual foi efetuada em cada uma das 36 quadrículas sorteadas e marcadas por amostragem simples, ao acaso, sem reposição (Raj, 1980), considerando-se a gleba como sendo composta por 364 quadrículas iguais, identificadas por sistema alfanumérico com as letras em ordem de $\mathrm{A}$ a $\mathrm{Z}$, de cima para baixo, e os números de 1 a 14 , da direita à esquerda, do plano da Figura 2. Assim sendo, foram coletados 36 conjuntos de dados para cada ICD em 14 ICD's nos dias 16 e 24 de novembro; 3, 14 e 19 de dezembro de $1995 ; 4,13,21$ e 29 de janeiro; 5, 12 e 17 de fevereiro; 5 e 13 de março de 1996.

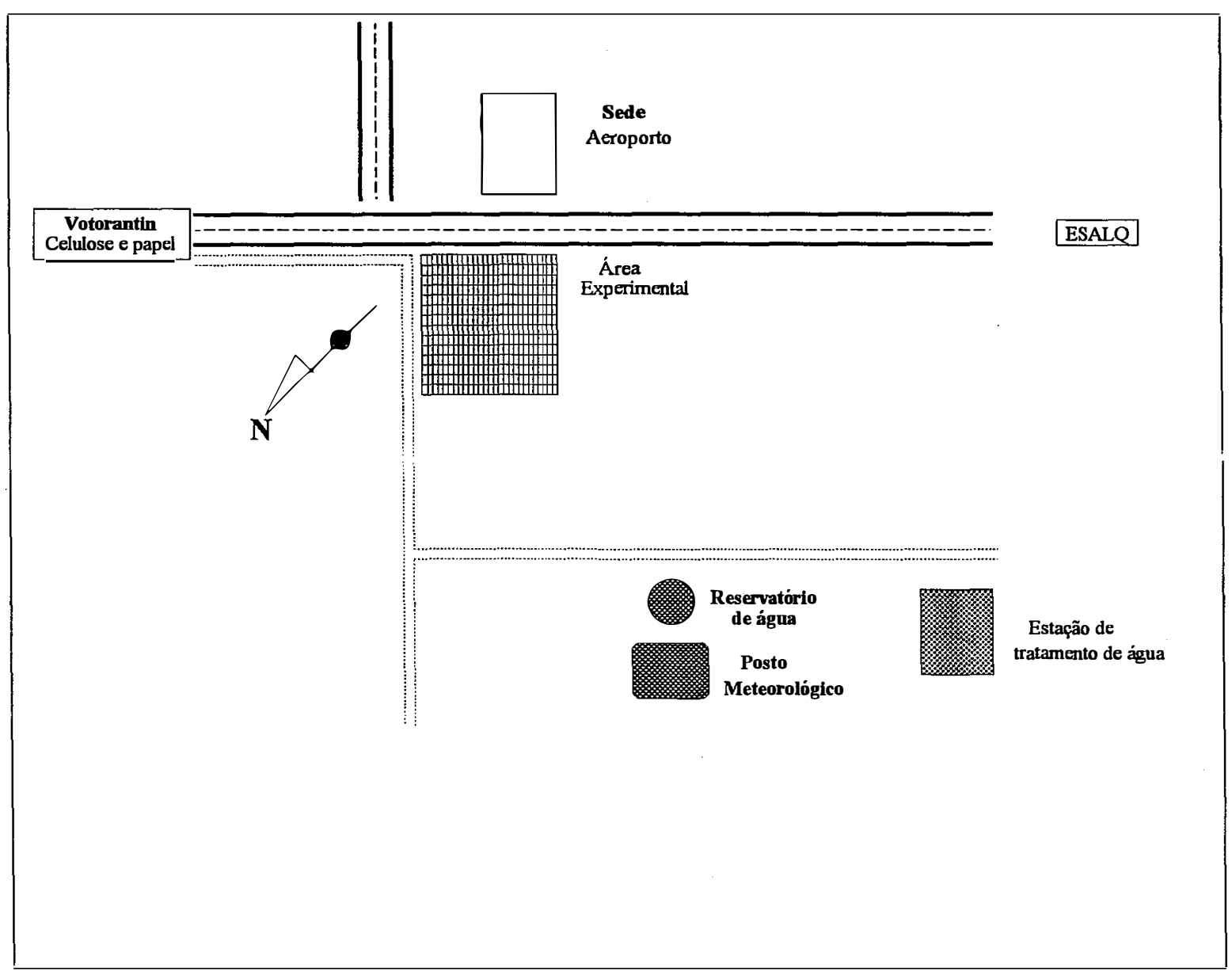

Figura 2. Figura esquemática da localização da gleba experimental. 


\subsubsection{Obtenção das fotografias}

Para a obtenção das fotografias foi utilizada uma máquina fotográfica com as seguintes características: Objetiva de 38-135 milímetros com f/3,2-8 e obturador automático; com formato de $24 \times 36$ milímetros; focalização automática, com controle auto foco ativo, com possibilidade de enfoque em ponto único; avanço automático do filme e ajuste automático de sua sensibilidade, para ASA 25 a 3200; e controle remoto.

Para sustentar a câmara 5 metros acima da superfície do solo foi utilizado um suporte metálico, construído na forma de $\mathrm{L}$ invertido com tubos de alumínio de 3 e 2,8 centímetros de diâmetro, com uma altura máxima de 6 e mínima de 3 metros, como ilustrado na Figura 3.

As fotografias foram tiradas no final da tarde ou com o tempo nublado, mantendo-se o suporte firme e em posição tal que o eixo ótico ficasse perpendicular a superfície do solo e que as linhas de cultura fossem enquadradas de modo a aparecerem paralelamente aos lados maiores das fotos.

Foram utilizados filmes de 35 milímetros, de 36 exposições, com ASA 100 para a obtenção de fotografias de $10 \times 15$ centímetros reveladas sempre pela mesma firma.

Tendo sido cronometrado o tempo gasto na obtenção de cada foto em cada local amostrado, obteve-se o tempo total gasto para o total das fotos obtidas no $13^{\circ} \mathrm{ICD}$, que corresponderam a 120 dias. 


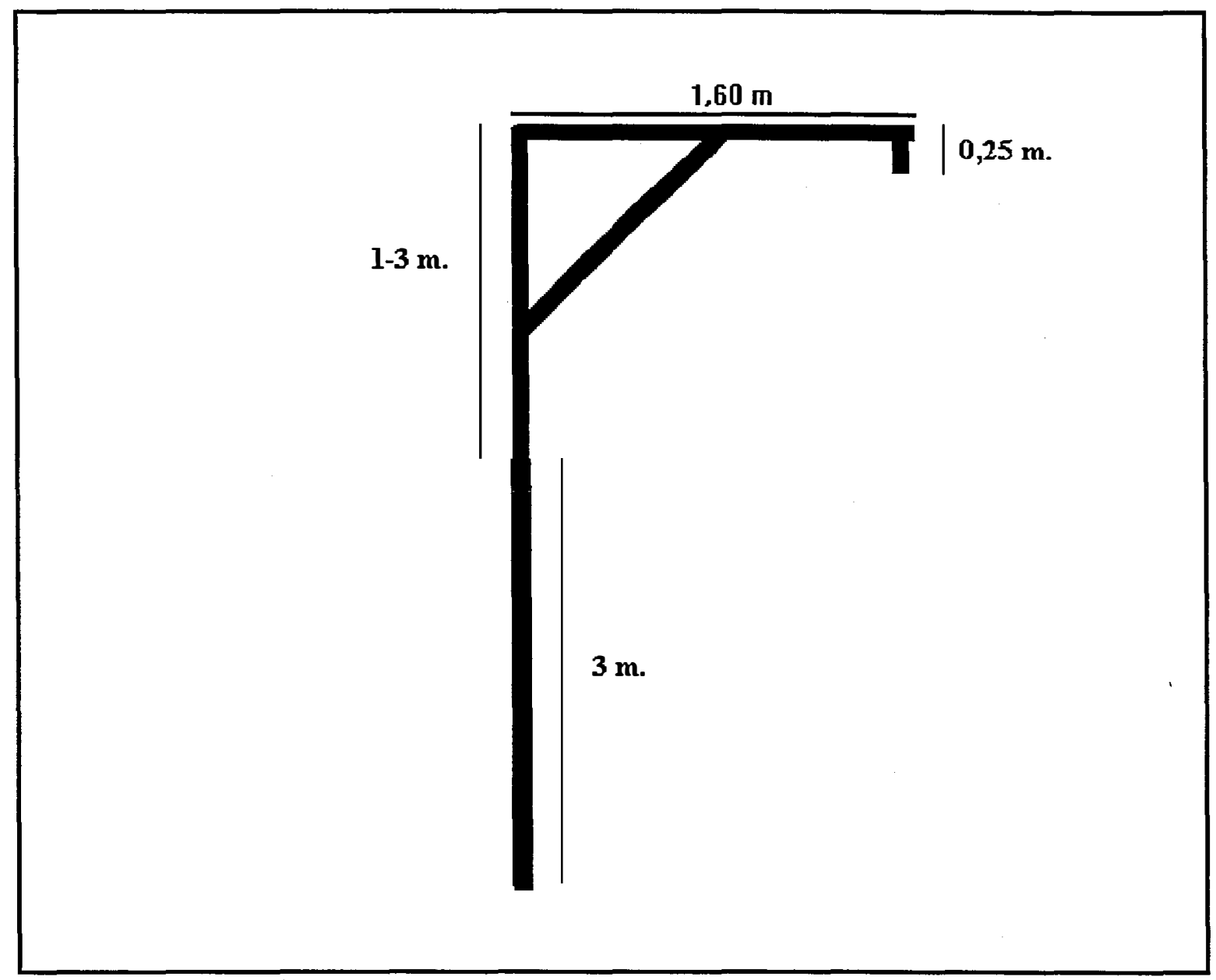

Figura 3. Desenho esquemático do suporte utilizado para posicionar a câmara acima da superfície do solo.

\subsubsection{Determinação da altura das plantas}

A altura das plantas foi medida com uma régua milimetrada, em direção perpendicular à superfície do solo, entre o colo da planta e o final da folha superior no ápice de crescimento ( $1^{\circ}$ ao $5^{\circ} \mathrm{ICD}$, inclusive), e entre aquele e a extremidade superior da haste central do pendão após a emissão deste $\left(6^{\circ}, 7^{\circ}\right.$ e $14^{\circ}$ ICD's) (Bragagnolo \& Mielniczuk, 1990). A planta medida foi aquela localizada à esquerda, a 1 metro da base do suporte da máquina fotográfica. 
A determinação da altura foi realizada até $o$ ponto de desenvolvimento máximo do pendão (68 dias após a semeadura), e no ultimo ICD, aos 128 dias após a semeadura.

\subsection{Processamento das fotografias}

Para evitar as distorções causada pela lente da máquina fotográfica, e para ocupar menos espaço de disco no computador, foi feita a seleção da parte central das fotografias (janela de $3 \times 3$ centímetros) conforme recomendação de Williams (1979). Através do uso de um scanner de mesa colorido, com resolução de 150 pontos por polegada, foi feita a transferência das imagens fotográficas para um microcomputador.

No microcomputador as imagens foram processadas de acordo com o SIARCS 3.0 (Sistema Integrado para Análise de Raízes e Cobertura do Solo), programa desenvolvido, na versão para WINDOWS 95, pelo CNPDIA da EMBRAPA, e que utiliza técnicas avançadas de processamento e análise de imagens para avaliar a distribuição de raízes de uma cultura e a porcentagem de cobertura vegetal do solo. Esse programa transforma a imagem colorida em uma imagem binaria (preto e branco) e, por meio de um algoritmo, faz a leitura de pontos pretos e brancos expressando o resultado em porcentagem de cobertura vegetal. O programa oferece as seguintes vantagens: maior precisão e rapidez em relação à contagem manual, criação de um arquivo de informações e imagens para estudo, e facilidade operacional (Jorge et al., 1993; Crestana et al., 1994 e EMBRAPA, s.d.). 


\subsection{Processamento e análise estatística dos dados}

Por meio do programa STATGRAPHICS 7.0 procedeu-se à localização de dados discrepantes (dados fora dos limites entre o quartil inferior e o quartil superior menos e mais 1,5 vezes a dispersão dos quartos, respectivamente), os quais foram eliminados segundo recomendação de Cahn et al. (1994).

Foi determinada, a cada ICD, a média, variância, desvio padrão e coeficiente de variação da porcentagem de cobertura vegetal do solo com a finalidade de se proceder ao re-dimensionamento das amostras, ou seja, para se estabelecer o número mínimo de fotos, e, conseqüentemente, a porcentagem mínima da área total cultivada a ser amostrada, para a obtenção da porcentagem de cobertura vegetal média.

Foi determinada, a cada ICD, a média, variância, desvio padrão, coeficiente de variação e feito o dimensionamento da amostra, com dados obtidos na metade (2730 metros quadrados), 1/4 (1365 metros quadrados), e 1/8 (682,5 metros quadrados) da área total do experimento com a finalidade de se verificar o efeito do tamanho da área sobre aqueles parâmetros estatísticos.

Foi determinada, a cada ICD, a média, variância, desvio padrão e coeficiente de variação da altura das plantas para se estabelecer o número mínimo de medidas considerado necessário para a obtenção da altura média das plantas.

Foram determinadas as taxas de crescimento em cada ICD, calculadas dividindo-se o valor da diferença entre as duas médias sucessivas, 
tanto de altura das plantas como de cobertura vegetal, obtidas no inicio e no fim do ICD pelo respectivo número de dias desse período.

Foram obtidas, com os valores médios, as curvas de evolução da percentagem de cobertura vegetal e da altura das plantas em função do tempo. Mediante a utilização da curva ajustada aos valores médios de cobertura vegetal, foram determinadas as datas correspondentes à ocorrência dos períodos das culturas apresentados por Wischmeier \& Smith (1978), para a lacalidade considerada.

Foi estudada a correlação entre os dados médios de porcentagem de cobertura e os correspondentes dados médios de altura das plantas, para ajuste da equação que permita utilizar os dados médios de altura das plantas na obtenção da curva de evolução da porcentagem de cobertura vegetal, nas condições do experimento.

A média, desvio padrão, variância, coeficiente de variação e dimensionamento da amostra foram calculados mediante o uso das seguintes fórmulas (Gomes, 1986):

$$
\begin{aligned}
& \bar{y}=\sum_{j=1}^{n} \frac{y_{j}}{n} \\
& \sigma^{2}=\frac{\sum_{j=1}^{n}\left(y_{j}-\bar{y}\right)^{2}}{n-1} \\
& \sigma=\sqrt{\sigma^{2}}
\end{aligned}
$$


$C . V .=\frac{\sigma}{\bar{y}} \cdot 100$

$$
\eta_{o}=\frac{t^{2} \cdot \sigma^{2}}{d^{2}}
$$

$$
\eta=\frac{\eta_{o}}{1+\frac{\eta_{o}}{N}}
$$

onde: $\bar{y}$ é a média da amostra, $y_{j}$ é o valor observado na j-esima repetição, $n$ é o número de amostras, $\sigma^{2}$ é a variância, $\sigma$ é o desvio padrão, $C . V$ é o coeficiente de variação, $\eta_{0}$ é o número de amostras necessário no caso de uma população infinita, $t$ é o valor da tabela de Student tomado com $(n-1)$ graus de liberdade, ao nível de probabilidade conveniente, $d$ é a precisão desejada (uma porção da média), $\eta$ é o número de amostras necessário no caso de uma população finita, e $N$ é o número total de indivíduos que compõem a população.

Foram utilizados valores para $\mathrm{t}$ com $5 \%$ de probabilidade de erro e 35 graus de liberdade para a amostra. O valor de precisão (d) utilizado foi de $10 \%$ da média da amostra. O valor de número de indivíduos $(N)$ foi de 364 parcelas para os valores de cobertura vegetal, sendo no caso da altura das plantas, a população considerada infinita. 


\section{RESULTADOS E DISCUSSÃO}

Neste capítulo são apresentados e discutidos inicialmente os resultados obtidos referentes à amostragem para determinação da porcentagem média de cobertura do solo pelo milho. A seguir são apresentados e discutidos os valores encontrados para a amostragem para determinação da altura média das plantas. Finalmente são apresentados os resultados do estudo de correlação entre esses dois parâmetros e uma série de considerações de ordem prática.

\subsection{Cobertura vegetal}

\subsubsection{Variação na porcentagem de cobertura vegetal}

Na Tabela 2 são apresentados os dados obtidos para o parâmetro cobertura vegetal, no período de 16 de novembro de 1995 a 13 de março de 1996. Da $3^{\mathrm{a}}$ até a $38^{\mathrm{a}}$ linhas, inclusive, estão colocados, na primeira coluna, os símbolos dos locais selecionados para a amostragem, e da segunda até mesmo a decima quarta coluna, os dados de cobertura vegetal, em porcentagem, obtidos para cada ICD, representado em dias após a semeadura. Da $39^{\mathrm{a}}$ à $44^{\mathrm{a}}$ linhas, inclusive, são apresentados os valores da 
Média, Desvio Padrão, Variância, Coeficiente de Variação, Número de amostras necessárias e Porcentagem da área a ser amostrada calculados com os dados de cobertura vegetal obtidos para cada ICD.

Nos locais e ICD's com valores em branco foram identificados e eliminados valores discrepantes conforme recomendação de Cahn et al. (1994), por aumentarem a variabilidade dos dados e conseqüentemente do Número de amostras calculado. Foram localizados valores discrepantes aos 10 e 18 dias após a semeadura no local 14-H; aos 43dias, nos locais 6-F e 11-L; aos 59 dias, nos locais 5-W e 11-M; e, aos 76 dias, nos locais 5-W, $10-Z, 12-\mathrm{T}$ e $14-\mathrm{G}$.

A media variou, assumindo do primeiro ao oitavo ICD os seguintes valores: 1,$40 ; 5,00 ; 20,20 ; 48,08 ; 62,33 ; 75,79 ; 76,24$ e 77,84 porcento de cobertura vegetal, com taxa média de incremento de 0,$14 ; 0,45 ; 1,52 ; 2,79$; 2,$85 ; 0,84 ; 0,05 ; 0,2$ porcento por dia; e do $9^{\circ}$ ao $14^{\circ}$ os valores de 74,36 ; 72,$13 ; 67,88 ; 67,77 ; 57,94$ e 47,36 porcento de cobertura vegetal, com taxa média de redução de $-0,44 ;-0,32 ;-0,61 ;-0,02 ;-0,58$ e $-1,32$ porcento, por dia. Observa-se que a média aumentou até o $76^{\circ}$ dia após a semeadura, decrescendo a partir daí até atingir valores próximos de 50\%, concordando com os estádios de crescimento apresentados por Fancelli (1990). 
Tabela 2. Valores de cobertura vegetal (\%), média (\%), desvio padrão, variância, coeficiente de variação e dimensionamento de amostra (No. de fotos) para cada um dos ICD's na área total.

\begin{tabular}{|c|c|c|c|c|c|c|c|c|c|c|c|c|c|c|}
\hline \multirow[b]{2}{*}{ Loc. Selec. } & \multicolumn{14}{|c|}{ Dias após a semeadura } \\
\hline & 10 & 18 & 28 & 38 & 43 & 59 & 68 & 76 & 84 & 91 & 98 & 103 & 120 & 128 \\
\hline $1-B$ & 1,95 & 6,49 & 27,93 & 42,66 & 64,56 & 78,01 & 81,19 & 71,69 & 56,34 & 56,60 & 53,46 & 53,98 & 40,91 & $\overline{62,01}$ \\
\hline $1-\mathrm{H}$ & 0,48 & $5, \varpi 3$ & 24,71 & 46,89 & 66,34 & 65,06 & 70,16 & 75,02 & 77,98 & 87,90 & 59,33 & 60,23 & 61,22 & 56,42 \\
\hline $1-R$ & 1,90 & 1,20 & 29,42 & 51,96 & 49,68 & 89,58 & 95,88 & 95,82 & 89,01 & 76,31 & 77,73 & 71,16 & 52,50 & 42,06 \\
\hline $1-V$ & 2,40 & 5,95 & 20,83 & $52, \varpi 3$ & 86,28 & 79,03 & 87,69 & 76,55 & 60,27 & 85,54 & 84,48 & 75,83 & 49,66 & 37,54 \\
\hline 2-G & 0,94 & 7,01 & 2,51 & 56,24 & 71,88 & 76,89 & 67,98 & 75,48 & 72,36 & 57,42 & 76,35 & 59,14 & 60,17 & 58,81 \\
\hline $2-0$ & 0,24 & 3,53 & 22,51 & 18,25 & 60,58 & 65,26 & 87,87 & 72,03 & 65,20 & 83,92 & 47,95 & 79,37 & 33,62 & 10,93 \\
\hline $3-A$ & 1,70 & 1,67 & 21,43 & $58, \widetilde{3}$ & 47,46 & 80,91 & 87,13 & 78,49 & 77,98 & 59,00 & 70,00 & 36,56 & 62,96 & 55,92 \\
\hline 3-L & 1,60 & 4,99 & 5,75 & 50,45 & 69,56 & 68,04 & 73,98 & 75,02 & 75,80 & 61,36 & 56,36 & 49,59 & 39,95 & 28,43 \\
\hline 3-Q & 1,46 & 0,75 & 5,99 & 42,55 & $\mathfrak{3 , \infty 0}$ & 60,56 & 60,44 & 60,32 & 59,87 & 62,58 & 65,50 & 57,89 & 56,53 & 57,88 \\
\hline 4-C & 1,45 & 4,24 & 21,01 & 45,64 & 70,74 & 68,21 & 77,90 & 74,54 & 72,40 & 59,42 & 65,19 & 65,28 & 67,38 & 64,38 \\
\hline $4-\mathrm{H}$ & 2,17 & 5,40 & 25,50 & 70,66 & 78,08 & 72,26 & 70,38 & 76,33 & 82,87 & $\varpi 3,04$ & 33,70 & 57,80 & 42,26 & 36,04 \\
\hline $4 W$ & $0, \varpi 3$ & 3,42 & 14,36 & 52,19 & 47,06 & 67,25 & 75,05 & 71,48 & 59,76 & 56,06 & 45,57 & 53,56 & 34,55 & 43,83 \\
\hline ו-5 & 2,03 & 4,13 & 20,27 & 57,60 & 68,65 & 77,34 & 84,10 & 91,30 & 70,42 & 61,14 & 59,49 & 51,92 & 77,14 & ๔3,16 \\
\hline $5-\mathrm{N}$ & 1,31 & $3, \mathfrak{3}$ & 15,43 & 47,52 & 58,18 & 79,33 & $85, \varpi 3$ & 84,62 & 84,84 & 85,15 & 90,65 & 86,87 & 42,29 & 29,59 \\
\hline $5-S$ & 1,09 & 10,02 & 27,05 & 47,15 & 57,21 & 81,20 & 89,35 & 69,02 & 87,45 & 69,27 & 55,62 & 62,38 & 77,33 & 62,00 \\
\hline $5-W$ & 1,79 & 2,10 & 13,51 & 47,66 & 55,04 & & 59,52 & & 51,24 & 59,84 & 57,49 & 44,85 & 23,81 & 17,83 \\
\hline $6-F$ & 1,29 & 7,03 & 25,53 & 47,08 & & 88,89 & 84,43 & 78,16 & 74,65 & 81,44 & 68,06 & 65,14 & 68,01 & 21,26 \\
\hline $7-B$ & $1, \varpi 3$ & 7,94 & 30,98 & 56,45 & 56,91 & 83,92 & 91,43 & 75,49 & 84,11 & 87,23 & 85,78 & 95,00 & 64,34 & 50,62 \\
\hline I-7 & 0,21 & 3,32 & 11,75 & 35,29 & 64,73 & 85,96 & 70,48 & 80,27 & 89,60 & 73,63 & 59,91 & 69,66 & 58,58 & 67,41 \\
\hline 7-L & 0,71 & 3,70 & 29,65 & 55,42 & 58,88 & 78,01 & 86,52 & 75,61 & 70,13 & 62,60 & 82,58 & 72,66 & 68,86 & 37,48 \\
\hline 8-D & 0,69 & 2,84 & $15, \widetilde{3}$ & 33,90 & 70,85 & 71,67 & 66,41 & 73,06 & 50,90 & 82,22 & 70,83 & 72,22 & 66,59 & 62,00 \\
\hline $8-H$ & 1,05 & 5,28 & 9,15 & 25,83 & 78,23 & 70,16 & $\widetilde{63,68}$ & 83,68 & 79,98 & 96,53 & 75,91 & 89,77 & 43,94 & 42,29 \\
\hline 9-J & 1,10 & 8,94 & 14,17 & $44, \varpi 3$ & 49,74 & 82,36 & 71,66 & 85,31 & 74,86 & 59,15 & 60,99 & 59,91 & 64,36 & 48,32 \\
\hline 9-P & 1,08 & 3,95 & 10,32 & 32,67 & 69,35 & 81,23 & 74,50 & 88,51 & 87,31 & 85,19 & 83,88 & 60,37 & 67,22 & 71,94 \\
\hline $10-0$ & 1,52 & 6,23 & 17,28 & 59,33 & 39,96 & 80,32 & 80,67 & 68,62 & 84,97 & 80,06 & 69,56 & 72,88 & 65,64 & 60,36 \\
\hline $10-P$ & 2,74 & 8,56 & 26,40 & 67,67 & 70,42 & 84,65 & 85,66 & 77,09 & 80,58 & 76,37 & 80,71 & 89,14 & 52,09 & 44,62 \\
\hline $10-Z$ & 2,57 & 2,70 & 21,45 & 40,94 & 61,61 & 82,64 & 74,88 & & 84,72 & 68,26 & 78,20 & 66,23 & 47,95 & 49,54 \\
\hline $11-L$ & 2,07 & 2,52 & 29,25 & 41,90 & & 90,69 & 80,08 & 73,94 & 80,01 & 67,05 & 67,90 & 74,48 & 74,27 & 55,16 \\
\hline $11-M$ & 1,87 & 0,81 & 21,52 & 35,82 & 58,36 & & 73,46 & 88,00 & 77,14 & 81,39 & 55,64 & 62,31 & 82,91 & 31,75 \\
\hline $12-T$ & 1,94 & 1,91 & 23,72 & 40,07 & 43,56 & 77,69 & 62,53 & & 65,16 & 51,25 & 54,31 & 90,07 & 56,85 & 35,49 \\
\hline $12-W$ & 1,05 & 5,99 & 9,69 & 38,32 & 70,62 & 69,30 & 63,43 & 86,60 & 65,03 & 80,82 & 74,37 & 79,32 & 53,17 & 49,51 \\
\hline $13-\mathrm{F}$ & 0,41 & 3,07 & 8,12 & 35,76 & 74,26 & 77,23 & 75,07 & 75,72 & 77,02 & 83,21 & 81,59 & 78,68 & 55,42 & 65,52 \\
\hline $13-K$ & 0,41 & 10,64 & 7,02 & 49,32 & 42,62 & 69,29 & 78,76 & 86,91 & 60,15 & 85,15 & 88,06 & 71,99 & 59,89 & 24,49 \\
\hline 14-D & 1,22 & 8,46 & 37,80 & 65,27 & 53,92 & 66,17 & 66,12 & 70,09 & 68,89 & 64,70 & 72,09 & 68,84 & 76,12 & 44,82 \\
\hline $14-G$ & 2,37 & 11,07 & 33,11 & 69,84 & 74,18 & 71,64 & 70,13 & & 84,39 & 71,45 & 70,40 & 82,31 & 54,35 & 52,51 \\
\hline $14-\mathrm{H}$ & & & 46,59 & 66,76 & 66,59 & 56,00 & 70,60 & 76,07 & 93,44 & 74,57 & 64,15 & 52,49 & 83,07 & $\mathfrak{6 3 , 0 8}$ \\
\hline Média & 1,40 & 5,00 & 20,20 & 48,08 & 62,33 & 75,79 & 76,24 & 77,84 & 74,36 & 72,13 & 67,88 & 67,77 & 57,94 & 47,36 \\
\hline Desv. Pad. & 0,68 & 2,82 & 9,86 & 12,20 & 11,22 & 8,47 & 9,52 & 7,53 & 11,28 & 11,82 & 13,14 & 13,71 & 14,28 & 15,40 \\
\hline Variância & 0,47 & 7,93 & 97,23 & 148,85 & 125,9 & 71,67 & 90,69 & 56,7 & 127,2 & 139,74 & 172,7 & 188,07 & 203,87 & 237,27 \\
\hline C.V. & 48,78 & 56,27 & 48,81 & 25,37 & 18,00 & 11,17 & 12,49 & 9,67 & 15,17 & 16,39 & 19,36 & 20,23 & 24,64 & 32,52 \\
\hline Amostra & 76 & 94 & 76 & 25 & 13 & 5 & 7 & 4 & 9 & 11 & 15 & 16 & 23 & 38 \\
\hline \% da área & 20,88 & 25,82 & 20,88 & 6,87 & 3,57 & 1,37 & 1,92 & 1,10 & 2,47 & 3,02 & 4,12 & 4,40 & 6,32 & 10,44 \\
\hline
\end{tabular}


Pode-se notar que de início os incrementos foram aumentando, até atingir um valor máximo entre o $38^{\circ}$ e o $43^{\circ}$ dias após a semeadura, no $5^{\circ}$ ICD, correspondente aproximadamente ao Estádio 3 descrito por Fancelli (1990), para em seguida diminuírem, mas mantendo valores positivos até o intervalo situado entre o $68^{\circ}$ e o $76^{\circ}$ dia, no $8^{\circ} \mathrm{ICD}$, correspondente aproximadamente ao Estádio 5. Entre o $76^{\circ}$ e o $84^{\circ}$ dias após a semeadura, no $9^{\circ} \mathrm{ICD}$, correspondente aproximadamente à passagem do Estádio 5 para o 6, o incremento da cobertura vegetal atingiu valor negativo, mantendo-se negativos os demais valores até o último ICD. Em valores absolutos, os maiores valores são observados no $4^{\circ}$ e $5^{\circ}$ ICD's. Os valores observados dos incrementos caracterizam a existência de três fases de evolução da cobertura vegetal: A primeira, de aumento rápido e crescente, que vai até o $5^{\circ} \mathrm{ICD}$; a segunda, de aumento lento e decrescente, que vai do $5^{\circ}$ ao $8^{\circ} \mathrm{ICD}$; e a terceira, de diminuição, do $8^{\circ} \mathrm{ICD}$ ao $14^{\circ} \mathrm{ICD}$. A evolução dos incrementos da porcentagem de cobertura vegetal tem sua explicação nas transformações morfológicas ocorridas nas plantas conforme os estádios descritos por Fancelli (1990), de modo que a redução da cobertura vegetal como função da senescência das plantas confirma o exposto por Arruda (1984).

\subsubsection{Redimensionamento do número de amostras}

O desvio padrão, na primeira fase, aumentou de 0,68 a 9,86 nos três primeiros ICD's assumindo os valores 12,20 e 11,22 no $4^{\circ}$ e $5^{\circ}$ ICD's respectivamente, para, a seguir, assumir os valores máximo de 9,52 e mínimo de 7,53 entre o $5^{\circ}$ e o $8^{\circ}$ ICD's, na segunda fase, e voltar a apresentar 
valores crescentes desde 11,28 no $9^{\circ}$ ICD até 15,40 no $14^{\circ} \mathrm{ICD}$. A variância por ser o quadrado do desvio padrão seguiu a mesma tendência. Esta tendência, ao contrário do relatado por Sallaway et al. (1988) é decrescente no intervalo estudado por esse autor. Essa discordância encontra explicação nas diferenças existentes entre os tipos de cobertura estudados (residuos vs. vegetação). A observação dos valores do coeficiente de variação, do número de amostras e da porcentagem da área necessária para a estimativa da média mostra também a existência de três fases na evolução da cobertura vegetal, a primeira fase indo do $1^{\circ}$ ao $5^{\circ} \mathrm{ICD}$, com uma subfase do $1^{\circ}$ ao $3^{\circ} \mathrm{ICD}$ 's e outra do $3^{\circ}$ ao $5^{\circ}$, a segunda fase do $5^{\circ}$ ao $8^{\circ}$ ICD's e a terceira do $8^{\circ}$ ao $14^{\circ}$ ICD's.

Não havendo simultaneidade no desenvolvimento das plantas (algumas germinam antes, e há inicialmente maior sensibilidade às condições próximas da planta) a variação dos parâmetros estatísticos mostra que a cobertura vegetal é mais heterogênea nos estádios que correspondem a uma fase de desenvolvimento vegetativo mais intenso, com maiores diferenças individuais na área foliar, e plantas ainda relativamente distanciadas. Tal ocorre nos ICD's em que os incrementos da porcentagem de cobertura vegetal aumentam rapidamente, até $05^{\circ} \mathrm{ICD}$, correspondendo aproximadamente ao Estádio 3 descrito por Fancelli (1990). Essa heterogeneidade inicial é contudo mais pronunciada na primeira subfase da primeira fase, do $1^{\circ}$ ao $3^{\circ}$ ICD's, diminuindo um pouco na segunda subfase quando alguma superposição de folhas compensa as diferenças individuais. A seguir, entrando na fase reprodutiva da cultura, enquanto algumas plantas tem a taxa de crescimento diminuída e vão sendo alcançadas por outras com 
taxa de crescimento ainda elevada, embora ainda haja aumento da cobertura vegetal, esse aumento é lento e decrescente e a cobertura vai se tomando mais homogênea, quando vão diminuindo as alterações nas folhas e a superposição de folhas é maior, o que ocorre até o $8^{\circ} \mathrm{ICD}$, correspondendo aproximadamente ao Estádio 5. Finalmente, no $9^{\circ} \mathrm{ICD}$, correspondendo aproximadamente ao Estádio 6, as plantas com desenvolvimento mais adiantado iniciam antes a perda de folhas, na fase de formação e maturação dos grãos, (havendo translocação dos sintetizados para a espiga e grãos) e novamente aumenta a heterogeneidade da cobertura vegetal. Nos primeiros três ICD's foram obtidos valores elevados dos três últimos parâmetros estatísticos, em decorrência da grande variação nos dados de cobertura obtidos nessa subfase, em concordância com Arruda (1984). Essa heterogeneidade inicial não pode ser explicada de acordo com Elwell \& Gardner (1976) uma vez que nos estádios posteriores ocorreu a tendência à homogeneização, sendo portanto essa heterogeneidade, em concordância com Fancelli (1990), decorrente da presença de diferenças localizadas nas condições de solo (alta rugosidade) no momento da semeadura mecanizada, associadas a diferenças na profundidade de semeadura. Esses três parâmetros diminuíram na medida que a cobertura vegetal aumentou, em concordância com Morrison et al. (1989).

A partir dos 38 dias após a semeadura os valores desses parâmetros diminuíram sensivelmente, especialmente entre o $5^{\circ}$ e o $8^{\circ}$ ICD's, quando o número de fotografias atingiu o valor mínimo de 4 e a porcentagem da área de $1,1 \%$, para logo aumentar novamente até 38 e 10,44\%, respectivamente, no último ICD. O número de fotografias e a porcentagem da área necessárias 
para estimar a média da cobertura vegetal do solo foi elevada na primeira sub-fase da primeira fase, razoável na segunda sub-fase da primeira fase e na terceira fase, e pequena na segunda fase. Em média foram necessárias 30 fotografias, o que equivale a $8,2 \%$ da área total, para estimar a média da amostra para uma área de 5460 metros quadrados. Essa média pode ser utilizada a partir do quarto até o penúltimo ICD’s. Este dado é semelhante ao encontrado por Elwell \& Gardner (1976) para as duas alturas estudadas com uma precisão de $\pm 5 \%$ da média.

Nas Tabelas 3, 4 e 5 são apresentados os resultados médios obtidos quando a área total do experimento foi dividida em duas sub-áreas de 2730 metros quadrados, em quatro de 1365 metros quadrados e em oito de 682,5 metros quadrados, respectivamente. Em todos os casos é visível a necessidade de maior número de amostras nos primeiros estádios da cultura devido à alta variação dos dados indicados por coeficiente de variação elevado concordando com Elwell \& Gardner (1976).

O número de fotografias necessária para estimar a média diminuiu na medida que diminuiu a área total a ser amostrada em concordância com Curram \& Williamson ${ }^{6}$. Isto é verdadeiro considerando só os valores médios da área total (Tabela 2), da metade da área (Tabela 3) e da oitava parte da área (Tabela 5). Os dados da Tabela 4 apresentam a partir do quarto ICD, inclusive, valores mais elevados do que os da Tabela 3 até o último ICD, e do que os da Tabela 2 até o $12^{\circ}$ ICD o que faz inviável sua inclusão na afirmação acima citada.

No entanto, a porcentagem de área a ser amostrada aumentou na medida que diminui a área total da parcela, o que é verificado na Tabela 6, 
que apresenta rearranjamento dos dados das Tabelas 2, 3, 4 e 5. A relação entre a área total da parcela e a porcentagem de área a ser amostrada é significativa, e é bem ajustada por uma curva exponencial com coeficiente de determinação de 0,95 como verificado na Figura 4.

Tabela 3. Valores da média de cobertura vegetal (\%), desvio padrão, variância, coeficiente de variação, dimensionamento da amostra (No. de fotos) e porcentagem da área a ser amostrada quando a área total foi dividida em duas sub-áreas.

\begin{tabular}{|c|c|c|c|c|c|c|c|c|c|c|c|c|c|c|}
\hline & \multicolumn{14}{|c|}{ Dias após a semeadura } \\
\hline & 10 & 18 & 28 & 38 & 43 & 59 & 68 & 76 & 84 & 91 & 98 & 103 & 120 & 128 \\
\hline Média & 1,41 & 5,07 & 20,25 & 47,95 & 62,25 & 75,7 & 75,85 & 78,1 & 74,51 & 72,47 & 68,27 & 68,32 & 58,42 & 47,63 \\
\hline Des. Pad. & 0,7 & 2,85 & 10,06 & 12,39 & 11,47 & 8,61 & 8,595 & 7,46 & 11,34 & 11,57 & 12,28 & 12,75 & 13,51 & 15,03 \\
\hline C.V. & 49,4 & 55,8 & 49,51 & 25,97 & 18,44 & 11,4 & 11,25 & 9,56 & 15,23 & 16 & 18,23 & 18,9 & 23,46 & 31,86 \\
\hline Amostra & 64 & 75 & 64 & 25 & 13 & 6 & 6 & 4 & 10 & 10 & 14 & 14 & 21 & 34 \\
\hline \% área & 35,2 & 40,9 & 35,16 & 13,46 & 7,143 & 3,02 & 3,022 & 2,2 & 5,22 & 5,495 & 7,418 & 7,692 & 11,26 & 18,68 \\
\hline
\end{tabular}

Tabela 4. Valores da média de cobertura vegetal (\%), desvio padrão, variância, coeficiente de variação, dimensionamento da amostra No. de fotos) e porcentagem da área a ser amostrada quando a área total foi dividida em quatro sub-áreas.

\begin{tabular}{|c|c|c|c|c|c|c|c|c|c|c|c|c|c|c|}
\hline & \multicolumn{14}{|c|}{ Dias após a semeadura } \\
\hline & 10 & 18 & 28 & 38 & 43 & 59 & 68 & $76^{-}$ & 84 & 91 & 98 & 103 & 120 & 128 \\
\hline Média & 1,44 & 4,95 & 19,90 & 47,58 & 61,83 & 75,92 & 76,05 & 78,09 & 74,43 & 72,52 & 68,52 & 68,88 & 57,21 & 47,19 \\
\hline 1 & 0,69 & 2,79 & 9,44 & 12,43 & 11,72 & 8,28 & 9,09 & 8,10 & 11,42 & 11,84 & 12,80 & 12,93 & 12,36 & 14,89 \\
\hline C.V & 49,11 & 57,38 & 46,75 & 26,36 & 19,09 & $11, \infty$ & 11,84 & 10,40 & 15,49 & 16,37 & 18,92 & 19,03 & 22,37 & 32,57 \\
\hline ost & 40 & 48 & 47 & 30 & 22 & 8 & 12 & 10 & 16 & 18 & 20 & 21 & 22 & 37 \\
\hline \% da área & 43,91 & 52,84 & 52,38 & 32,98 & 24,21 & 8,68 & 13,45 & 11,70 & 17,79 & 19,96 & 22,21 & 23,26 & 24,72 & 40,87 \\
\hline
\end{tabular}


Tabela 5. Valores da média de cobertura vegetal (\%), desvio padrão, variância, coeficiente de variação, dimensionamento da amostra (No. de fotos) e porcentagem da área a ser amostrada quando a área total foi dividida em oito sub-áreas.

\begin{tabular}{|c|c|c|c|c|c|c|c|c|c|c|c|c|c|c|}
\hline & \multicolumn{14}{|c|}{ Dias após a semeadura } \\
\hline & 10 & 18 & 28 & 38 & 43 & 59 & 68 & 76 & 84 & 91 & 98 & 103 & 120 & 128 \\
\hline Média & 1,44 & 5,01 & 19,90 & 47,58 & 61,86 & 76,11 & 76,05 & 78,56 & 74,43 & 72,52 & 68,52 & 68,88 & 57,21 & 47,19 \\
\hline Desv. Pad. & 0,73 & 2,61 & 9,27 & 9,68 & 11,84 & 7,44 & 8,49 & 6,88 & 10,93 & 10,96 & 12,54 & 12,69 & 12,04 & 14,77 \\
\hline C.V. & 51,53 & 56,05 & 46,00 & 20,03 & 19,11 & 9,90 & 11,04 & 8,90 & 14,99 & 15,39 & 18,66 & 18,61 & 21,88 & 32,67 \\
\hline Amostra & 31 & 31 & 29 & 12 & 11 & 4 & 5 & 4 & 8 & 8 & 11 & 11 & 13 & 21 \\
\hline$\%$ da área & 68,24 & 6,47 & 64,09 & 27,52 & 25,15 & 9,29 & 10,89 & 8,73 & 18,32 & 18,59 & 24,35 & 23,85 & 28,55 & 46,29 \\
\hline
\end{tabular}

Tabela 6. Valores da área mínima (\%) a ser amostrada em função do tamanho da área total $\left(\mathrm{m}^{2}\right)$ e do tempo.

\begin{tabular}{ccccccccccccccc}
\hline & \multicolumn{10}{c}{ Dias após a semeadura } \\
\cline { 2 - 11 } Área $\left(m^{2}\right)$ & 10 & 18 & 28 & 38 & 43 & 59 & 68 & 76 & 84 & 91 & 98 & 103 & 120 & 128 \\
\hline 682,5 & 68,24 & 69,47 & 64,09 & 27,52 & 25,15 & 9,29 & 10,89 & 8,73 & 18,32 & 18,59 & 24,35 & 23,85 & 28,55 & 46,29 \\
1365 & 43,91 & 52,84 & 52,38 & 32,98 & 24,21 & 8,68 & 13,45 & 11,70 & 17,79 & 19,96 & 22,21 & 23,26 & 24,72 & 40,87 \\
2730 & 35,16 & 40,93 & 35,16 & 13,46 & 7,14 & 3,02 & 3,02 & 2,20 & 5,22 & 5,49 & 7,42 & 7,69 & 11,26 & 18,68 \\
5460 & 20,88 & 25,82 & 20,88 & 6,87 & 3,57 & 1,37 & 1,92 & 1,10 & 2,47 & 3,02 & 4,12 & 4,40 & 6,32 & 10,44 \\
\hline
\end{tabular}

\subsubsection{Curva de evolução da cobertura vegetal em função do tempo}

Na Figura 5 são apresentadas a curva de evolução da cobertura vegetal no tempo e sua respectiva equação, deśde o primeiro ICD, de zero a 10 dias, até os 76 dias após a semeadura, quando a cobertura vegetal é máxima, sendo esse intervalo da relação mais do que suficiente, segundo Wischmeier \& Smith (1978), para permitir a obtenção dos dados necessários para o cálculo do fator $\mathrm{C}$ da Equação Universal de Perda de Solo. A relação altamente significativa entre as duas variáveis é representada por uma equação logística ponderada, com coeficiente de determinação elevado $\left(\mathrm{r}^{2}=0,99\right)$. Curvas de crescimento da cobertura vegetal, de formato 
semelhantes, foram encontrados por Manering \& Johnson (1969), Elwell \& Wendelaar (1977) e Arruda (1984), mesmo quando os valores máximo e finais foram ligeiramente maiores.

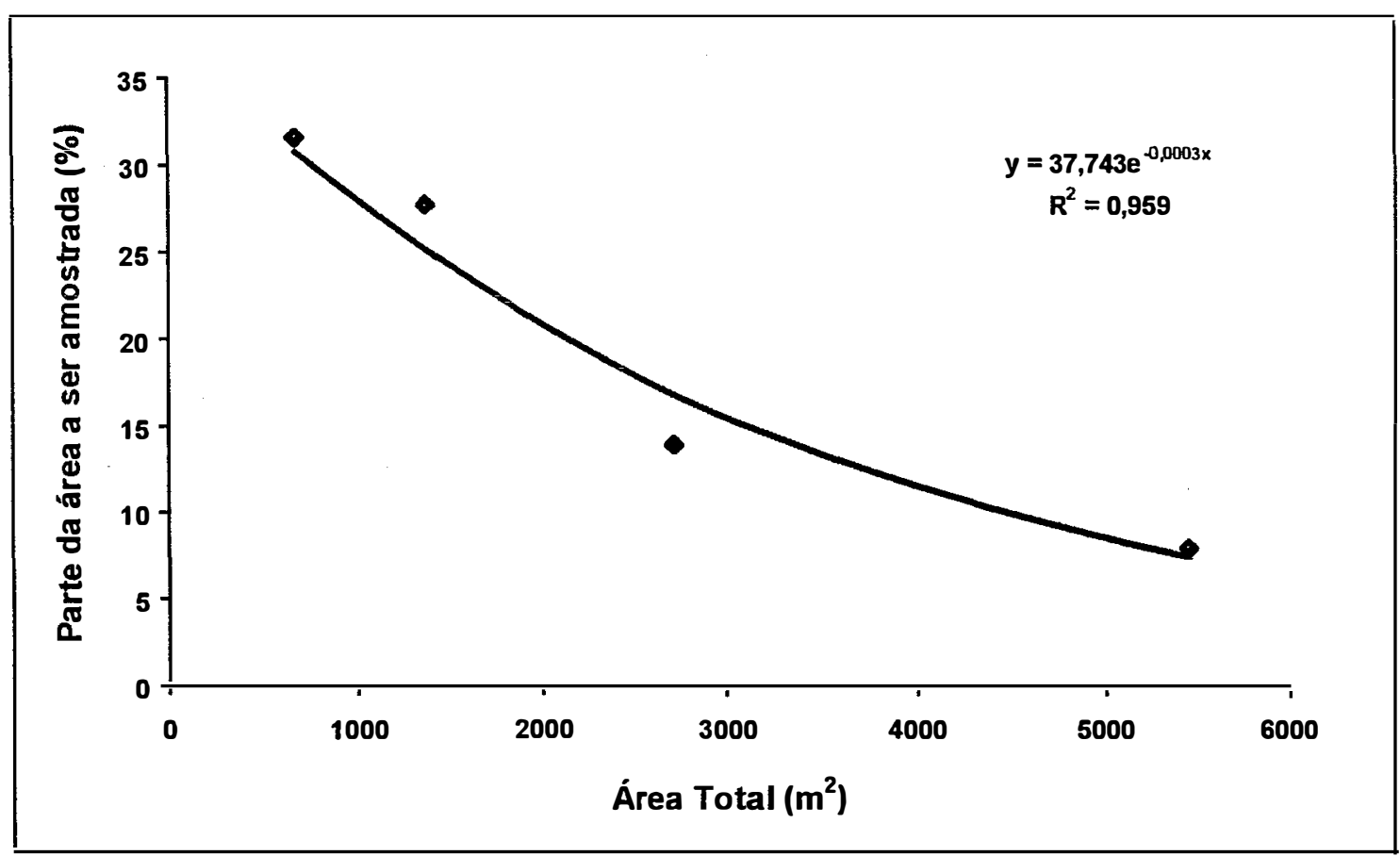

Figura 4. Relação entre a área total e a porcentagem de área mínima a ser amostrada.

Verifica-se que o híbrido do milho utilizado, cultivado de acordo com as técnicas de manejo empregadas, pode contribuir no controle da erosão do solo, uma vez que apresentou elevada taxa de aumento da porcentagem de cobertura, tendo atingido acima de $70 \%$ de cobertura do solo nos meses de janeiro e fevereiro, quando ocorre em média cerca de $42 \%$ da erosividade da chuva na região, ocorrendo em média cerca de $72 \%$ durante todo o ciclo da cultura. 


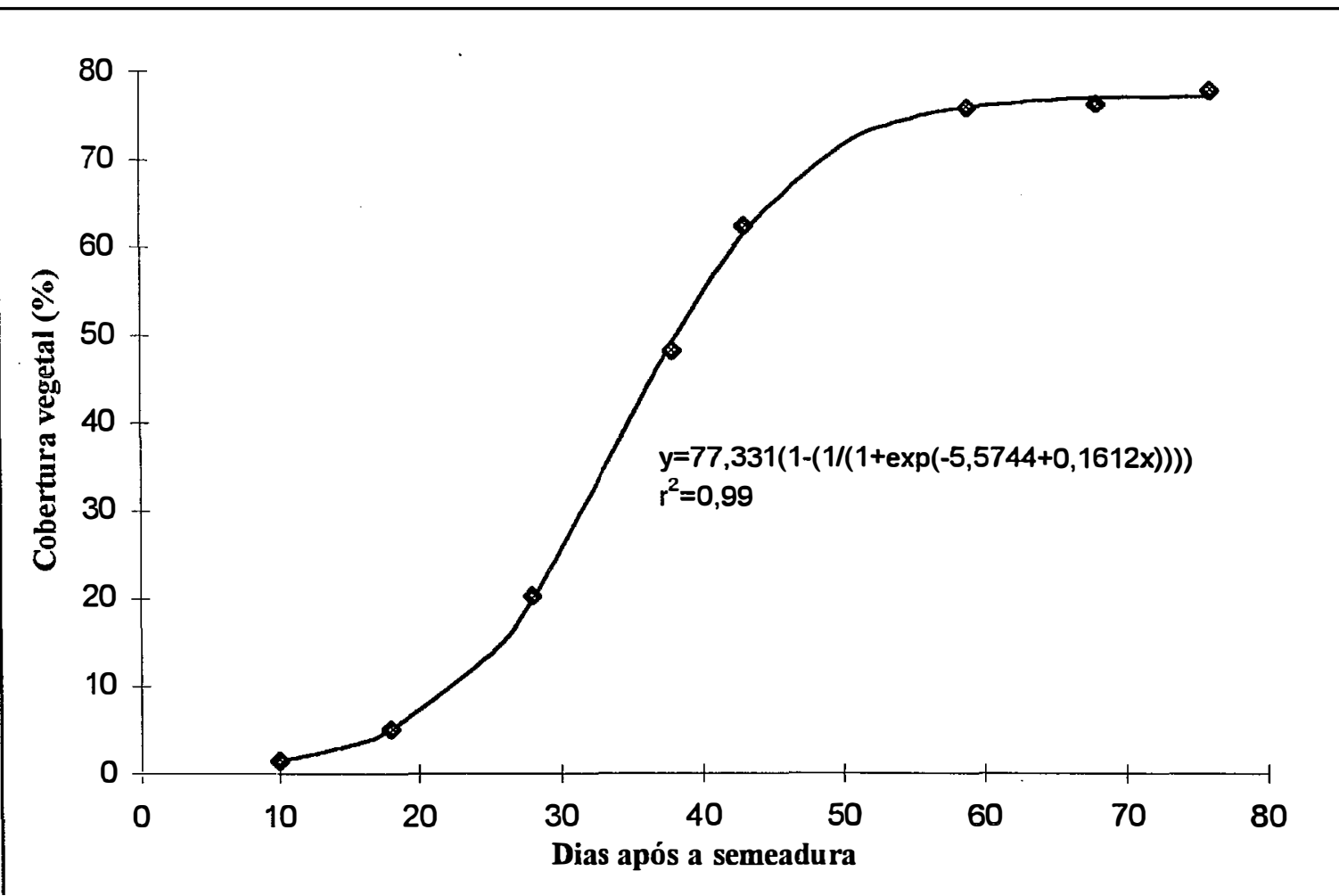

Figura 5. Evolução da porcentagem de cobertura do solo pelo milho (\%) em função do tempo.

\subsubsection{Períodos da cultura no processo erosivo}

Com a equação da Figura 5 é possível calcular os valores de cobertura vegetal para cada um dos períodos citados por Wischmeier \& Smith (1978), a seguir:

Período F: de 1 até 6 de novembro de 1995.

Período SB: de 6 até 29 de novembro de 1995 ou 23 dias após a semeadura.

Período 1: de 29 de novembro a 15 de dezembro de 1995 ou 39 dias após a semeadura. 
Período 2: de 15 de dezembro de 1995 a 2 de janeiro de 1996 ou 57 dias após a semeadura.

Período 3: de 2 de janeiro até 29 de março de 1996 ou 139 dias após a semeadura.

Período 4: de 29 de março até 12 de abril de 1996 ou 153 dias após a semeadura do milho.

Estes períodos diferem muito dos encontrados por De Maria (1995), devido às diferenças de caracter genético entre os cultivares, da metodologia e localidades utilizados em ambos estudos.

\subsection{Altura das plantas}

\subsubsection{Variação na altura das plantas}

Na Tabela 7 são apresentados os dados correspondentes à altura das plantas, em centímetros, da mesma forma como o foram os dados referentes a cobertura vegetal do solo, sendo que neste caso, a determinação da altura foi realizada até o ponto de desenvolvimento máximo do pendão (68 dias após a semeadura), a partir de quando este parâmetro permaneceu constante. Foi realizada ainda uma última determinação no último ICD, aos 128 dias após a semeadura quando se observou uma pequena diminuição da altura decorrente da quebra da ponta dos pendões por senescência da planta.

Da mesma forma como ocorreu com os dados de cobertura vegetal, foram eliminados os dados discrepantes. Assim, aos 18 dias após a 
semeadura foi localizado e eliminado um valor discrepante no local 14-G; aos 28, no local 12-W; aos 59, nos locais 1-R, 8-D e 14-H; e, aos 68, nos locais $1-\mathrm{R}$ e $1-\mathrm{V}$.

Pode-se observar que a altura média das plantas aumentou até os 68 dias após a semeadura, quando atingiu o seu valor máximo de 284,8 centímetros, em concordância com o final do estádio 4 e o inicio do estádio 5 apresentados por Fancelli (1990). Neste período ocorreu o aparecimento total do pendão, e com o início da emissão dos estilo-estigmas, cessaram as elongações do colmo e internódios.

As taxas de crescimento, em cada ICD, foram de $0,86,0,79,2,11$, $4,06,6,89,8,08,4,95$, e $-0,14$ centímetros por dia. Observa-se uma alta taxa de crescimento entre os 28 e 68 dias após a semeadura decorrentes do início do processo fotossintético até o florescimento como indicado por Fancelli (1990). O último valor corresponde à taxa experimentada entre os $68^{\circ}$ e $128^{\circ}$ dias após a semeadura, no qual se observa um valor negativo, devido à diminuição da altura como foi explicado anteriormente.

O desvio padrão e a variância aumentaram até os 59 dias para logo ter uma queda aos 68, e aumentar novamente aos 128 dias após a semeadura. O coeficiente de variação alcançou valores elevados nos primeiros três ICD's, entre 20,76 e $28,23 \%$; logo depois caiu para valores entre 14,59 e $14,82 \%$, nos dois ICD's seguintes, para nos últimos três ICD's, tomar valores máximo de 7,10 e mínimo de 3,23, ou seja, o coeficiente de variação diminuiu na medida que a altura das plantas aumentou, em concordânıcia com os valores encontrados para cobertura vegetal. 
Tabela 7. Valores de altura da planta $(\mathrm{cm})$, média $(\mathrm{cm})$, desvio padrão, variância, coeficiente de variação (\%) e o número calculado de amostras (No. de plantas) necessárias, para os dados obtidos em cada um dos ICD's.

\begin{tabular}{|c|c|c|c|c|c|c|c|c|}
\hline \multirow[b]{2}{*}{ Loc. Selec. } & \multicolumn{8}{|c|}{ Dias após a semeadura } \\
\hline & 10 & 18 & 28 & 38 & 43 & 59 & 68 & 128 \\
\hline $1-B$ & 12,00 & 13,30 & 26,00 & 56,20 & 87,50 & 216,00 & 300,00 & 294,00 \\
\hline $1-\mathrm{H}$ & 10,00 & 17,90 & 41,50 & 90,20 & 113,90 & 239,00 & 299,00 & 292,00 \\
\hline $1-R$ & 7,00 & 12,60 & 38,00 & 75,50 & 104,10 & & & 241,00 \\
\hline $1-V$ & 5,00 & 8,20 & 23,60 & 68,90 & 91,50 & 214,00 & & 254,00 \\
\hline 2-G & 8,70 & 16,40 & 28,40 & 65,60 & 94,00 & 198,00 & 278,00 & 304,00 \\
\hline $2-0$ & 10,00 & 11,50 & 30,60 & 81,00 & 113,90 & 245,00 & 288,00 & 310,00 \\
\hline $3-A$ & 7,50 & 15,40 & 37,80 & 94,00 & 126,00 & 256,00 & 287,00 & 270,00 \\
\hline $3-L$ & 7,20 & 17,00 & 35,30 & 83,70 & 119,50 & 251,00 & 285,00 & 270,00 \\
\hline 3-Q & 8,70 & 16,90 & 35,10 & 90,30 & 125,00 & 251,00 & 300,00 & 300,00 \\
\hline 4-C & 7,00 & 10,50 & 42,10 & 88,10 & 103,20 & 251,00 & 286,00 & 284,00 \\
\hline $4-\mathrm{H}$ & 11,00 & 13,00 & 35,80 & 71,40 & 100,50 & 227,00 & 278,00 & 250,00 \\
\hline $4-W$ & 5,50 & 9,50 & 43,40 & 70,80 & 94,50 & 235,00 & 278,00 & 278,00 \\
\hline $5-1$ & 8,50 & 11,50 & 37,00 & 82,50 & 102,00 & 243,00 & 275,00 & 278,00 \\
\hline $5-\mathrm{N}$ & 7,00 & 9,00 & 36,20 & 68,50 & 106,70 & 222,00 & 291,00 & 293,00 \\
\hline $5-S$ & 6,50 & 8,70 & 36,00 & 75,80 & 128,50 & 240,00 & 278,00 & 282,00 \\
\hline $5-W$ & 7,80 & 19,40 & 41,10 & 58,50 & 87,20 & 235,00 & 287,00 & 287,00 \\
\hline $6-F$ & 7,50 & 21,00 & 36,00 & 69,30 & 107,00 & 229,00 & 285,00 & 251,00 \\
\hline 7-B & 7,00 & 12,00 & 41,30 & 73,40 & 98,90 & 254,00 & 294,00 & 287,00 \\
\hline I-I & 6,00 & 17,50 & 42,20 & 85,50 & 120,70 & 247,00 & 288,00 & 286,00 \\
\hline 7-L & 10,00 & 9,50 & 24,20 & 59,50 & 105,00 & 238,00 & 281,00 & 280,00 \\
\hline 8-D & 6,00 & 11,00 & 20,00 & 60,00 & 83,50 & & 285,00 & 283,00 \\
\hline $8-\mathrm{H}$ & 11,50 & 13,50 & 23,80 & 58,90 & 94,50 & 218,00 & 287,00 & 268,00 \\
\hline 9-J & 8,50 & 15,50 & 33,50 & 79,00 & 127,70 & 268,00 & 285,00 & 274,00 \\
\hline 9-P & 9,20 & 16,20 & 21,00 & 62,10 & 80,50 & 232,00 & 285,00 & 275,00 \\
\hline $10-0$ & 7,00 & 17,50 & 37,00 & 69,90 & 115,00 & 248,00 & 264,00 & 268,00 \\
\hline $10-P$ & 8,80 & 23,00 & 50,00 & 96,10 & 130,80 & 251,00 & 288,00 & 265,00 \\
\hline $10-Z$ & 7,80 & 10,50 & 36,00 & 80,50 & 126,50 & 244,00 & 301,00 & 261,00 \\
\hline $11-L$ & 9,50 & 17,00 & 41,20 & 76,10 & 123,00 & 272,00 & 276,00 & 269,00 \\
\hline $11-M$ & 12,00 & 14,50 & 40,00 & 77,00 & 111,20 & 241,00 & 278,00 & 273,00 \\
\hline $12-T$ & 9,50 & 23,50 & 36,00 & 80,80 & 111,00 & 236,00 & 285,00 & 280,00 \\
\hline $12-W$ & 10,00 & 14,50 & & 81,40 & 113,70 & 206,00 & 280,00 & 270,00 \\
\hline $13-F$ & 9,00 & 17,50 & 45,00 & 74,00 & 113,00 & 248,00 & 274,00 & 267,00 \\
\hline $13-K$ & 11,00 & 18,90 & 33,90 & 75,00 & 117,90 & 259,00 & 302,00 & 265,00 \\
\hline 14-D & 12,00 & 14,90 & 37,00 & 88,50 & 131,50 & 256,00 & 268,00 & 263,00 \\
\hline $14-G$ & 9,20 & & 48,00 & 91,10 & 143,00 & 258,00 & 275,00 & 287,00 \\
\hline $14-\mathrm{H}$ & 9,00 & 23,10 & 45,30 & 98,10 & 145,10 & & 291,00 & 282,00 \\
\hline Média & 8,61 & 14,91 & 35,98 & 76,59 & 111,04 & 240,24 & 284,76 & 276,14 \\
\hline Desvio Padrão & 1,88 & 4,21 & 7,47 & 11,35 & 16,20 & 17,06 & 3,21 & 15,21 \\
\hline Variância & 3,55 & 17,72 & 55,80 & 128,84 & 262,37 & 291,13 & 84,85 & 231,38 \\
\hline c.v. & 21,88 & 28,23 & 20,76 & 14,82 & 14,59 & 7,10 & 3,23 & 5,51 \\
\hline Amostra & 20 & 32 & 18 & 9 & 9 & 3 & 1 & 2 \\
\hline
\end{tabular}


A variação observada nos dados da Tabela 7 indicam a ocorrência de maior heterogeneidade na altura das plantas nos primeiros 3 ICD's correspondentes ao final do estádio 0 , e os estádios 1 e início do 2 da cultura (Fancelli, 1990). As causas de tal heterogeneidade foram devidamente explicados quando foram discutidos os dados de cobertura vegetal neste mesmo período. Nos estádios posteriores, com o desenvolvimento do sistema radicular, as plantas já não são tão afetadas pelos fatores então citados na discussão da variação da cobertura vegetal, além do que as operações de cultivo e o uso de irrigação tendem a uniformizar as condições de solo, e com o desenvolvimento da cobertura vegetal, a sombra das plantas maiores provoca maior taxa de desenvolvimento da altura das plantas menores, o que resulta na tendência de nivelamento da altura das plantas. Ocorre também que as plantas tendem a se nivelar em altura na medida em que vão entrando no estádio 5 (nona e décima semanas após a emergência), descrito por Fancelli (1990), quando cessam as elongações do colmo e internódios.

\subsubsection{Redimensionamento do número de amostras}

As variações observadas, anteriormente citadas, provocaram resultados analogamente variáveis nos correspondentes valores do Número de Amostras Calculado, cuja tendência foi a mesma do coeficiente de variação. Nos últimos 5 ICD's foram atingidos o valor máximo de 9 , aos 38 e aos 43 dias, e mínimo de 1, aos 68 dias. A máxima homogeneidade na altura das plantas foi observada no $7^{\circ} \mathrm{ICD}$, correspondente ao fim do quarto 
e inicio do quinto estádios da cultura, quando as plantas ao saírem dos estádios mais vegetativos param de crescer e todas vão atingindo pouco mais ou pouco menos a mesma altura. Essa homogeneidade diminuiu no último ICD, correspondente ao estádio 10 em face das diferenças individuais de comportamento das plantas nas fases de produção de espigas e maturação.

\subsubsection{Curva de evolução da altura das plantas em função do tempo}

Na Figura 6 é apresentada a evolução da altura das plantas no tempo. As médias se ajustam a uma equação logística, com os dados transformados pelo logaritmo natural, com alto nível de significância $(F \geq 0,01)$ e coeficiente de determinação alto $\left(\mathrm{r}^{2}=0,99\right)$. Essa equação é válida desde os 10 dias após a semeadura até o ponto de desenvolvimento máximo do pendão, aos 68 dias após a semeadura. A seguir com a parada do crescimento esse parâmetro tende a se estabilizar próximo ao valor da altura máxima.

\subsubsection{Correlação entre a altura das plantas e a cobertura vegetal}

Na Figura 7 são plotados os dados de altura das plantas e cobertura vegetal, desde a semeadura até os 68 dias após o plantio, data que coincide com a emissão total do pendão. Observa-se um alto coeficiente de correlação entre as variáveis estudadas de 0,99 . Até os 43 dias após a semeadura, na medida que aumentam os valores de altura das plantas, aumentam os valores de cobertura vegetal em forma proporcional o que daria uma correlação linear entre estes parâmetros. A seguir, e até os 68 dias após a semeadura, os 
aumentos de cobertura vegetal não acompanham linearmente os aumentos em altura e a curva, como um todo, passa a ter uma tendência quadrática.

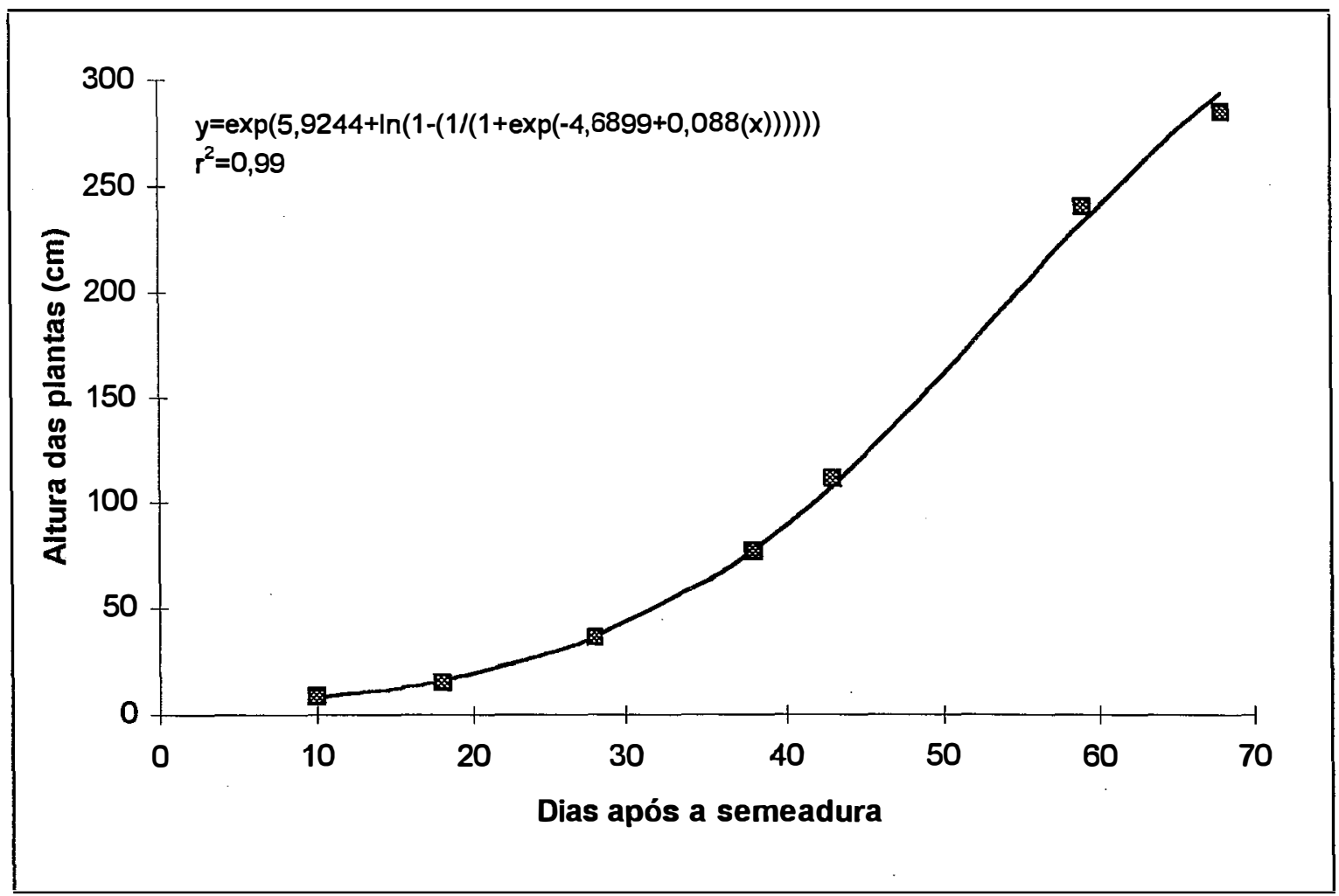

Figura 6. Evolução da altura da planta (cm) em função do tempo.

Isto é conseqüência de que a partir dos 43 dias após a semeadura as plantas começam a ocupar todo o espaço das entrelinhas e iniciam a superposição das folhas, de modo que o aumento da cobertura vegetal vai sendo reduzido.

Uma alta correlação entre estes parâmetros foi encontrada por De Maria et al. (1989). 


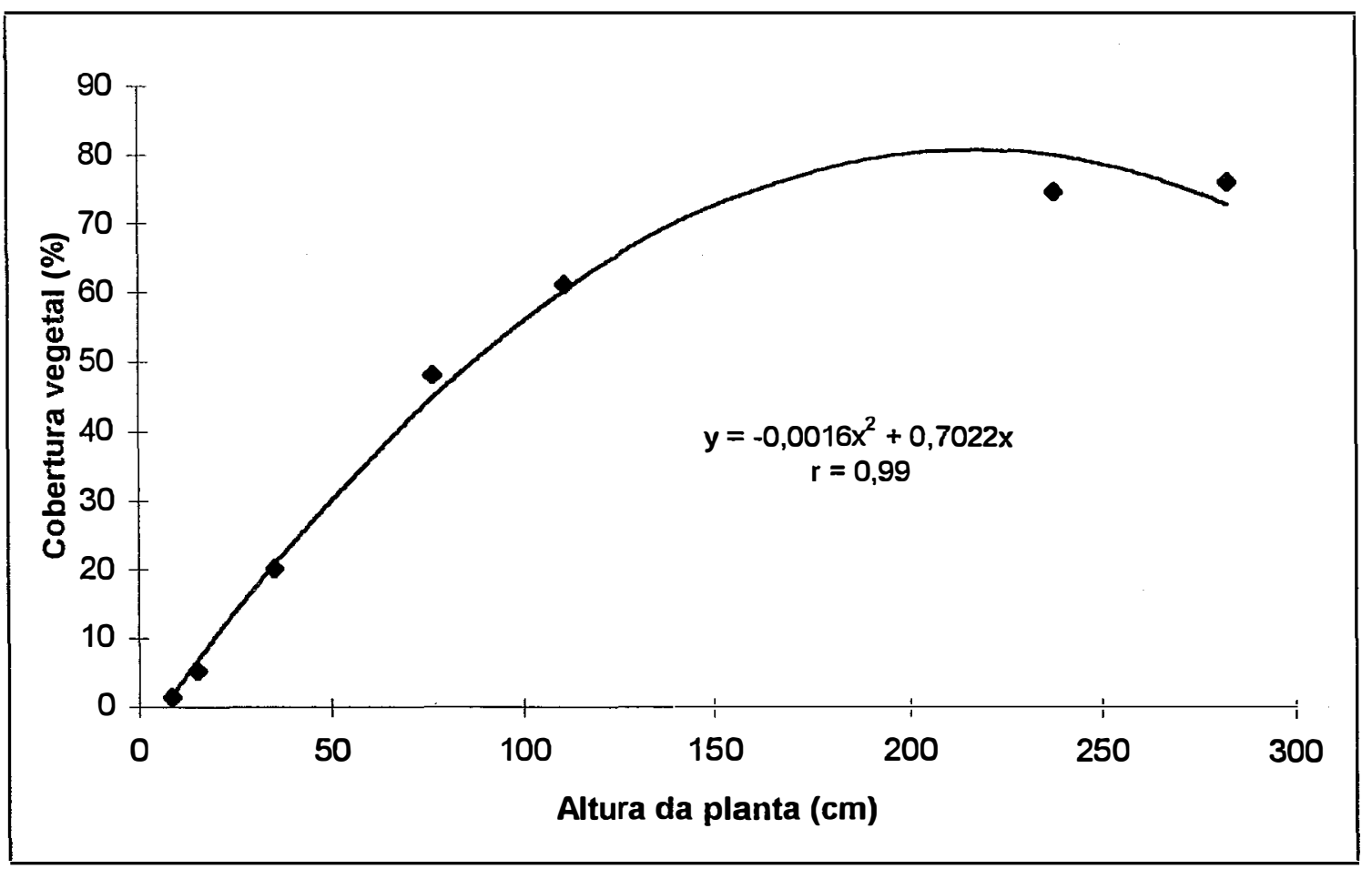

Figura 7. Relação entre a cobertura vegetal (\%) e a altura da planta $(\mathrm{cm})$ do milho.

\subsection{Considerações de ordem prática sobre a utilização do método} fotográfico

A estrutura metálica, construída com tubos de alumínio, ao contrário da utilizada por Vasques Filho ${ }^{5}$ (1995), além de ser fácil de transportar ofereceu a vantagem de ser leve e assim poder ser operada, por apenas dois operários, em concordância com Elwell \& Gardner (1976). Além disso, as articulações colocadas na estrutura permitiram o seu transporte até em pequenos automóveis, evitando a necessidade do uso de trator ou camionetas para esse fim como descrito por Elwell \& Gardner (1976) e Vasques Filho ${ }^{5}$ (1995). Apesar da praticidade da estrutura metálica utilizada, teve-se dificuldade para sujeitá-la com apenas um operário em dias de muito 
vento, ainda mais por estar seu peso maior localizado na sua parte mais alta; em tais ocasiões houve aumento do tempo de obtenção das fotografias assim como dos riscos de causar danos à maquina fotográfica e a cultura, contrariamente ao observado por Elwell \& Wendelaar (1977), Hartwig \& Laflen (1978), Arruda (1984) e Sallaway et al. (1988).

Considerando-se que os dados de cobertura vegetal correspondentes a cada parcela deveriam formar uma série crescente até um valor máximo e decrescente a partir daí, tal como ocorre com a série de valores médios, alguns dados anômalos são observados na Tabela 2. Tais anomalias são o resultado da ação do vento nas folhas no momento da tomada das fotos. Embora, segundo Elwell \& Wendelaar (1977), o método fotográfico seja pouco sensível a esse tipo de problema, tal método teve sua sensibilidade ampliada no caso presente, quando no processamento da imagem foi utilizada a menor área possível das fotografias, afim de que fosse evitado o erro decorrente da distorção de imagem causada pela lente da máquina fotográfica.

Os resultados apresentados na Tabela 8 , indicam que a coleta dos dados aos 120 dias após a semeadura, se iniciou às 17:59 horas e terminou às 19:26 horas, o que significa que 36 fotografias foram tiradas em um intervalo de 1 hora e 27 minutos. Eliminando os valores mais elevados da Tabela 8 , ou seja 13 e 6 minutos, que correspondem a fotos tomadas em distâncias maiores do que a distância média entre as parcelas, são necessários em média 2,06 minutos ( 2 mininutos e 3 segundos) para a obtenção de uma fotografia com o método e os materiais utilizados. Esse tempo concorda com os resultados obtidos por Arruda (1984) e discorda 
daqueles obtidos por Williams (1979) e Jong Van Lier et al. (1993) devidos à altura e peso da estrutura metálica por eles utilizadas.

Tabela 8. Tempo utilizado para a obtenção das fotografias aos 120 dias após a semeadura.

\begin{tabular}{cccccc}
\hline Hora & Tempo(min) & Hora & Tempo(min) & Hora & Tempo(min) \\
\hline $17: 59$ & & $18: 42$ & 1 & $19: 05$ & 2 \\
$18: 03$ & 3 & $18: 45$ & 3 & $19: 06$ & 1 \\
$18: 06$ & 3 & $18: 47$ & 2 & $19: 09$ & 3 \\
$18: 19$ & 13 & $18: 49$ & 2 & $19: 11$ & 2 \\
$18: 22$ & 3 & $18: 50$ & 1 & $19: 12$ & 1 \\
$18: 24$ & 2 & $18: 52$ & 2 & $19: 14$ & 2 \\
$18: 27$ & 3 & $18: 54$ & 2 & $19: 15$ & 1 \\
$18: 31$ & 4 & $18: 55$ & 1 & $19: 21$ & 6 \\
$18: 34$ & 3 & $18: 56$ & 1 & $19: 22$ & 1 \\
$18: 36$ & 2 & $18: 58$ & 2 & $19: 23$ & 2 \\
$18: 38$ & 2 & $19: 01$ & 3 & $19: 24$ & 1 \\
$18: 41$ & 3 & $19: 03$ & 2 & $19: 26$ & 2 \\
\hline
\end{tabular}

A transferência das fotografias para o computador realizada através do "scanner" ocupou um tempo total de 5 dias com 8 horas diárias de trabalho. Assim, pode-se considerar que uma série de 36 fotos, que correspondem a um ICD, levou 2 horas e 51 minutos para sua transferência, o que equivale a 4 minutos e 45 segundos para cada fotografia. A leitura da cobertura vegetal através do SIARCS foi realizada em um período de 7 dias, num total de 56 horas, o que equivale a 4 horas por cada ICD e 6 minutos e 40 segundos por cada fotografia. A análise da imagem fotográfica desde a transferência até a leitura da cobertura vegetal consumiu, para cada fotografia, um tempo igual a 11 minutos e 25 segundos. Esse tempo é superior ao encontrado por Elwell \& Gardner (1976), Lowery et al. (1984) e 
Morrison \& Chichester (1991), e muito inferior aos encontrados por Arruda (1984), Morrison et al. (1989) e Corak et al. (1993).

Essas diferenças podem ser explicadas como apresentado por Han \& Hayes (1990), sendo que teoricamente a classificação da imagem pelo algoritmo deveria ser mais consistente do que o método de contagem de malha regular de pontos, desde que o primeiro examina a imagem toda, e classifica 3840 sub-imagens, no entanto o segundo examina só de 100 a 200 pontos em uma imagem.

A hora mais propicia para a utilização do método é no final da tarde ou com céu nublado, devido ao melhor contraste entre a vegetação e o solo evitando dessa maneira a aparição de sombras das plantas acima do solo, o que dificulta o trabalho com o programa, em contraposição à afirmação de Adams \& Arkin (1977) e Arruda (1984). Além disso, foi observada a necessidade de utilização de uma fonte de iluminação adicional mais potente do que o "flash" da máquina fotográfica, devido a que nas fotografias utilizadas foi difícil a distinção entre plantas, resíduos e solo, particularmente na sombra das folhas superiores coincidindo assim com a afirmação de Elwell \& Gardner (1976) e Thomas et al. (1988). Uma alternativa para minimizar este problema pode ser a cobertura da área a ser fotografada, para evitar a incidência direta da luz solar, e a utilização de um "flash" eletrônico, mais potente, capaz de fornecer a quantidade adequada de luz tanto em dias nublados como em dias ensolarados segundo-o proposto por Meyer et al. (1988).

A fórmula para calcular a área fotografada, apresentada pelo GREF (1991), que foi utilizada por causa da forma retangular da fotografia e do 
negativo, difere daquela utilizada por Williams (1979). Os cálculos efetuados concordam com os de Lowery et al. (1984) e Meyer et al. (1988), e diferem dos de Corak et al. (1993) que apresentaram resultados ligeiramente inferiores aos calculados pela fórmula acima citada, e dos de Sallaway et al. (1988) que não colocaram a distância focal da lente utilizada.

A utilização do método fotográfico não provocou danos à cultura, confirmado-se assim a conclusão de Elwell \& Wendelaar (1977).

Finalmente, e concordando com Han \& Hayes (1990), pesquisas adicionais são necessárias para determinar o tamanho da sub imagem e a resolução espacial a serem utilizadas, o que poderia reduzir o tempo de processamento das fotografias. 


\section{CONCLUSÕES}

Os resultados obtidos nas condições do presente experimento permitem concluir que:

A altura das plantas, pela facilidade e pelo baixo custo de sua determinação, por requerer um número relativamente pequeno de amostras para a obtenção de valores médios, dentro dos limites de precisão e exatidão utilizados, e por seu elevado coeficiente de correlação com a porcentagem de cobertura vegetal do solo, aparentemente representa uma altemativa promissora como parâmetro estimador desta variável.

O método fotográfico tem sua eficiência aumentada em áreas com cobertura mais homogênea que permitam a utilização de pequenas áreas de amostragem.

O método fotográfico mostrou menor eficiência nos primeiros estádios da cultura, quando a variabilidade em termos de porcentagem de cobertura determinou a necessidade de aumento da área amostrada e, portanto, de utilização de um número muito grande de fotos, com as conseqüentes elevações de custo e consumo de tempo.

$\mathrm{O}$ material e as técnicas empregados no presente estudo aumentaram a eficiência do Método Fotográfico. 


\section{REFERÊNCIAS BIBLIOGRÁFICAS}

ADAMS, J. E.; ARKIN, G. R. A light interception method for measuring row crop ground cover. Soil Science Society of America Journal, v. 41, n. 4, p. 789-792, 1977.

ANDRADE, J. M. S.; OCUMPAUGH, W. R. Transector: an inexpensive device to measure ground cover and botanical composition of swards. Agronomy Journal, v. 71, n. 2, p. 369-370, 1979.

ARRUDA, F. V. Determinação da cobertura do solo durante o ciclo das culturas. Revista Brasileira de Ciência do Solo, v. 8, n. 1, p. 145150, 1984.

BERTONI, J.; LOMBARDI NETO, F. Conservação do solo. 3a.ed. São Paulo: Ícone, 1990. 355 p.

BERTONI, J.; PASTANA, F. I.; LOMBARDI NETO, F; BENATTI JUNIOR, R. Conclusões gerais das pesquisas sobre conservação do solo no Instituto Agronômico. Campinas: Instituto Agronômico, 1972. 56 p. (IAC. Circular, 20).

BRAGAGNOLO, N; MIELNICZUK, J. Cobertura do solo por resíduos de oito seqüências de culturas e seu relacionamento com a temperatura 
e umidade do solo, germinação e crescimento inicial do milho. Revista Brasileira de Ciência do Solo, v.14, n. 1, p. 91-98, 1990.

BRASKALB. Produtividade sem concorrência: informações técnicas. s.1., 1996. $38 \mathrm{p}$.

CAHN, M. D.; HUMMEL, J. W.; BROUER, B. H. Spatial analysis of soil fertility for site-specific crop management. Soil Science Society of America Journal, v. 58, p. 1240-1248, 1994.

COGO, N. P.; AMADO, T. J. C. Avaliação da exatidão do método fotográfico utilizado na determinação da porcentagem de cobertura do solo por resíduos culturais. In: CONGRESSO BRASILEIRO DE CONSERVAÇÃO DO SOLO, 6.; ENCONTRO NACIONAL DE PESQUISA SOBRE CONSERVAÇÃO DO SOLO, 6.; Campo Grande, 1986. Resumo. Campinas: Fundação Cargill, 1986. p. 98.

CORAK, S. J.; KASPAR, T. C.; MEEK, D. W. Evaluating method for measuring residue cover. Journal of Soil and Water Conservation, v. 48, n. 1, p. 70-74, 1993.

CRESTANA, S.; GUIMARAES, M. F.; JORGE, L. A. C.; RALISH, R.; TOZZI, C. L.; TORRE, A.; VAZ, C. M. P. Avaliação da distribuição de raízes no solo auxiliada por processamento de imagens digitais. Revista Brasileira de Ciencia do Solo, v. 18, n. 3, p. 365-371, 1994. 
DE MARIA, I. C.; LOMBARDI NETO, F.; DECHEN, S.C.F.; VIEIRA, S.R.; NASCIMENTO, P.C. do. Avaliação da cobertura vegetal da cultura do milho. In: CONGRESSO BRASILEIRO DE CIÊNCIA DO SOLO, 22., Recife, 1989. Programas e resumos. Recife: Sociedade Brasileira de Ciência do Solo, 1989. p. 240-241.

DE MARIA, I. C. Razão de perdas de solo para alguns sistemas de manejo da cultura de milho. Piracicaba: 1995. 93 p. Tese (Doutorado) - Escola Superior de Agricultura "Luiz de Queiroz", Universidade de São Paulo.

ELWELL, H. A.; GARDNER S. Comparison of two techniques for measuring percent crop canopy cover of row crops in erosion research programmes. Harare: Department of Conservation and Extension, Institute of Agricultural Engineering, 1976. 20 p. (Research Bulletin, 19).

ELWELL H. A.; WENDELAAR, F. E. To initiate a vegetal cover data bank for soil loss estimation. Harare: Department of Conservation and Extension, Institute of Agricultural Engineering, 1977. 42 p. (Research Bulletin, 23).

Empresa Brasileira de Pesquisa Agropequaria. Centro Nacional de Pesquisa e Desenvolvimento de Intrumentação Agropecuária. 
SIARCS: sistema integrado para análise de raízes e cobertura do solo. São Carlos, s.d. 2p.

FANCELLI, A. L. Tecnologia da produção. In: FANCELLI, A. L.; LIMA, U. A. Milho: produção, pré-processamento e transformação agroindustrial. Piracicaba: FEALQ, 1990. pt. A, p. 1-68. (Série Extensão Agroindustrial, 5).

FAO PRODUCTION YEARBOOK - 1994, v. 48, p. 8 , 77, 1995.

GOMES, F.P. Curso de amostragem no campo florestal. Piracicaba: ESALQ, 1986. $51 \mathrm{p}$.

GOMES, J.; KARASAWA, M. Cultura do milho no estado de Paraná. Londrina: IAPAR, 1979. 29 p. (Circular 13).

GRUPO DE REELABORAÇÃO DO ENSINO DE FISICA. Fisica 2: física térmica/óptica. São Paulo: EDUSP, 1991. 367 p.

HAN, Y. J.; HAYES, J. C.. Soil cover determination by image analysis of textural information. Transactions of the ASAE, v. 33, n. 2, p. 681686, 1990. 
HARTWIG, R. O.; LAFLEN J. M. A meterstick method for measuring crop residue cover. Journal of Soil and Water Conservation, v. 33, n. 2, p. 90-91, 1978.

JONG VAN LIER, Q. de; SPAROVEK, G.; VASQUES FILHO, J. Análise de imagens utilizando um "scanner" manual: aplicações em agronomia. Revista Brasileira de Ciência de Solo, v. 17, n. 3, p. 479-482, 1993.

JORGE, L. A. C.; DE MARIA, I. C.; LOMBARDI NETO, F.; CRESTANA, S. Avaliação da cobertura do solo por culturas através de processamento de imagens. In: CONGRESSO BRASILEIRO DE CIÊNCIA DO SOLO, 24., Goiânia, 1993. Resumo. Goiânia, SBCS, 1993. v.3, p. 139-40.

LAFLEN, J. M.; AMEMIYA, M.; HINTZ, E. A. Measuring crop residue cover. Journal of Soil and Water Conservation, v. 36, n. 6, p. 341$343,1981$.

LOWERY, B.; LILLESAND, T. M.; MUELLER,D. H.; WEILER, P.; SCARPACE, F. L.; DANIEL, T. C. Determination of crop residue cover using scanning microdensitometry. Journal of Soil and Water Conservation, v. 39, n. 6, p. 402-403, 1984. 
MANNERING, J. V.; JOHNSON, C. B. Effect of crop row spacing on erosion and infiltration. Agronomy Journal, v. 61, n. 6, p. 902-905, 1969.

MEYER, G. E.; STEPANEK, A.; SHELTON, D. P.; DICKEY, E. C. Electronic image analysis of crop residue cover on soil. Transactions of the ASAE, v. 31, n. 3, p. 968-973, 1988.

MORRISON, J. E.; CHICHESTER, F. W. Still video image analysis of crop residue soil covers. Transactions of the ASAE, v. 34, n. 6, p. 2469-2474, 1991.

MORRISON, J. E.; CHICHESTER, F. W.; ESCOBAR, D. E. Measurement of residue cover with dot screens. Journal of Soil and Water Conservation, v. 44, n. 5, p. 542-544, 1989.

PEREIRA, V. P.; MALHEIROS, E. B.; RAGAZZI, W. L.; ZANON J. C. Comparação entre alguns métodos fotográficos e o método meterstick, para avaliação de cobertura de resíduos de culturas no solo, com modelos simulados. In: CONGRESSO BRASILEIRO DE CONSERVAÇÃO DO SOLO, 6.; ENCONTRO NACIONAL DE PESQUISA SOBRE CONSERVAÇÃO DO SOLO, 6.; Campo Grande, 1986. Resumo. Campinas: Fundação Cargill, 1986. p. 99. 
PIERSON, B. J.; LEWIS, C. E.; BIRKLID, C. A.. Observer differences in determining crop residue cover in the Alaskan subartic. Journal of Soil and Water Conservation, v. 88, n. 6, p. 493-495, 1988.

RAJ, D. Teoría del muestreo. Mexico: Fondo de Cultura Económica, 1980. $305 \mathrm{p}$.

RANZANI, G.; FREIRE, O.; KINJO, T. Carta de solos do município de Piracicaba. Piracicaba: ESALQ, Centro de Estudos de Solos, 1966. $85 \mathrm{p}$.

SALLAWAY, M. M.; LAWSON, D.; YULE, D. F. Ground cover during fallow from wheat, sorghum and sunflower stubble under three tillage practices in Central Queensland. Soil \& Tillage Research, v. 12, n. 4, p. 347-364, 1988.

SLONEKER, L. L.; MOLDENHAUER, W. C. Measuring the amounts of crop residue remaining after tillage. Journal of Soil and Water Conservation, v.32, n. 5, p. 231-236, 1977.

THOMAS, D. L.; SLVA, F. J. K. da; CROMER, W . A. Image processing for plant canopy cover evaluation. Transactions of the ASAE, v. 31, n. 2, p. 428-434, 1988. 
WILLIAMS, T. H. L. An error analysis of the photographic technique for measuring percent vegetative cover. Soil Science Society of America Journal, v. 43, n. 3, p. 578-582, 1979.

WIMBUSH, D. J.; BARROW, M. D.; COSTIN, A. B. Color stereophotography for the measurement of vegetation. Ecology, v. 48, n. 1, p. 150-152, 1967.

WISCHMEIER, W. H. Cropping-management factor evaluations for a universal soil loss equation. Soil Science Society of America Proceedings, v. 24, p. 322-326, 1960.

WISCHMEIER, W. H.; SMITH, D. D. Predicting rainfall erosion losses : a guide to conservation planning. Washington: USDA, 1978. 58 p. (Agricultural Handbook, 537). 